\title{
Interleukin-6 in Allogeneic Stem Cell Transplantation: Its Possible Importance for Immunoregulation and As a Therapeutic Target
}

\author{
Tor Henrik Anderson Tvedt ${ }^{1,2 *}$, Elisabeth Ersvaer ${ }^{3}$, Anders Aune Tveita ${ }^{4}$ \\ and Øystein Bruserud ${ }^{1,2}$
}

${ }^{1}$ Department of Clinical Science, Section for Hematology, University of Bergen, Bergen, Norway, ${ }^{2}$ Department of Medicine, Haukeland University Hospital, Bergen, Norway, ${ }^{3}$ Institute of Biomedical Laboratory Sciences and Chemical Engineering, Western Norway University of Applied Sciences (HVL), Bergen, Norway, ${ }^{4}$ Department of Immunology and Transfusion Medicine, Oslo University Hospital, Oslo, Norway

OPEN ACCESS

Edited by:

Martin Johannes Hoogduijn, Erasmus University Rotterdam,

Netherlands

Reviewed by:

Amir Ahmed Toor,

Virginia Commonwealth University,

United States

Ignacio Anegon,

University of Nantes, France

*Correspondence:

Tor Henrik Anderson Tvedt

kundens@hotmail.com

Specialty section:

This article was submitted to Alloimmunity and Transplantation, a section of the journal

Frontiers in Immunology

Received: 22 February 2017

Accepted: 22 May 2017

Published: 08 June 2017

Citation:

Tvedt TH, Ersvaer E, Tveita AA and Bruserud Ø (2017) Interleukin-6 in Allogeneic Stem Cell Transplantation:

Its Possible Importance for

Immunoregulation and As a

Therapeutic Target.

Front. Immunol. 8:667.

doi: 10.3389/fimmu.2017.00667
Allogeneic stem cell transplantation is associated with a high risk of treatment-related mortality mainly caused by infections and graft-versus-host disease (GVHD). GVHD is characterized by severe immune dysregulation and impaired regeneration of different tissues, i.e., epithelial barriers and the liver. The balance between pro- and anti-inflammatory cytokine influences the risk of GVHD. Interleukin-6 (IL-6) is a cytokine that previously has been associated with pro-inflammatory effects. However, more recent evidence from various autoimmune diseases (e.g., inflammatory bowel disease, rheumatoid arthritis) has shown that the IL-6 activity is more complex with important effects also on tissue homeostasis, regeneration, and metabolism. This review summarizes the current understanding of how pro-inflammatory IL-6 effects exerted during the peritransplant period shapes T-cell polarization with enhancement of Th17 differentiation and suppression of regulatory $T$ cells, and in addition we also review and discuss the results from trials exploring non-selective IL-6 inhibition in prophylaxis and treatment of GVHD. Emerging evidence suggests that the molecular strategy for targeting of IL-6-initiated intracellular signaling is important for the effect on GVHD. It will therefore be important to further characterize the role of IL-6 in the pathogenesis of GVHD to clarify whether combined IL-6 inhibition of both trans(i.e., binding of the soluble IL-6/L-6 receptor complex to cell surface gp130) and cis-signaling (i.e., IL-6 ligation of the IL-6 receptor/gp130 complex) or selective inhibition of trans-signaling should be tried in the prophylaxis and/or treatment of GVHD in allotransplant patients.

Keywords: interleukin-6, cytokine receptor gp130, allogeneic stem cell transplantation, graft-versus-host disease, Janus kinases

\footnotetext{
Abbreviations: ADAM, a disintegrin and metalloproteinase; AP-1, activator protein 1; ASCT, allogeneic stem cell transplantation; C/EBP- $\alpha$, CCAAT/enhancer-binding protein alpha; CCL, chemokine (C-C motif) ligand 5; CNTF, ciliary neurotrophic factor; CRP, C-reactive proteins; CT-1, cardiotrophin-1; CT-2, cardiotrophin-2; DAMPs, damage-associated molecular patterns; APC, antigen-presenting cells; MHC, major histocompatibility complex; EGF, epidermal growth factor; ERK, extracellular signal-regulated kinases; FOXP3, forkhead box P3; GATA-3, globin transcription factor 3; GM-CSF, granulocyte-macrophage colony-stimulating factor; gp130, glycoprotein 130; GPL, gp130-like; GVHD, graft-versus-host disease; IBMTR, Center for International Blood \& Marrow Transplant Research; ICAM-1, intercellular adhesion molecules; IFN- $\gamma$, interferon gamma; IL, interleukin; IL-6R, IL-6 receptor alpha; JAK, Janus kinase; LIF, leukemia inhibitory factor; LIFR, leukemia inhibitory factor receptor; MAPK, mitogen-activated protein kinase; MSCs, mesenchymal stem cells; NFAT, nuclear factor of activated T cells; NF- $\mathrm{kB}$, nuclear factor kappa-light-chain-enhancer of activated B cells; NP, neuropoetin; OCM, oncostatin M; OSMR, oncostatin M receptor; PAMPs, pathogen-associated molecular patterns; RAF, rapidly accelerated fibrosarcoma; RAS, rat sarcoma; ROR $\gamma$ T, RAR-related orphan receptor gamma; sIL-6R, soluble IL-6R; SNP, single nucleotide polymorphism; SOCS, suppressor of cytokine signaling; STAT, signal transducer and activator of transcription; TCR, T-cell receptor; Tfh, follicular B helper T cells; TGF, transforming growth factor; Th, T helper cells; TLR, toll-like receptor; TNF $\alpha$, tumor necrosis factor alpha; Tregs, regulatory T cells; TYK, tyrosine kinase; VCAM-1, vascular cell adhesion protein 1; YAP1, yes-associated protein 1.
} 


\section{INTRODUCTION}

Allogeneic stem cell transplantation (ASCT) is a potentially curative therapeutic modality used primarily in the treatment of hematological malignancies and bone marrow failure syndromes $(1,2)$. Despite better supportive care and increased understanding of the underlying pathophysiology processes, the majority of patients will experience either acute or chronic graft-versus-host disease (GVHD) (3).

Graft-versus-host disease is a complex biological process, which includes severe immune dysregulation with sustained inflammation (4). Several studies have identified interleukin-6 (IL-6) and as an important factor in the pathophysiology of GVHD $(5,6)$. IL-6 is an important cytokine involved in both acute and chronic inflammation, and it plays a major role in several autoimmune disorders (7-9). It also mediates strong anti-inflammatory effects important for immunoregulation, metabolic control, and tissue regeneration (10). During the last 15 years the pleiotropic effects of IL-6 in different organ systems have been reveled, and anti-IL- 6 treatment has been approved for autoimmune and neoplastic disorders (11). With increasing insight into the complex signaling events induced by IL-6, more specific blockade of the anti-inflammatory functions of IL-6 is under development.

\section{ASCT AND GVHD}

In current ASCT protocols an initial conditioning treatment with chemotherapy and/or total body irradiation is followed by infusion of a stem cell graft derived from either umbilical cord blood, bone marrow, or peripheral blood of a healthy donor. Severe GVHD occurs in $20-30 \%$ of adult allotransplant recipients and is an important cause of transplant-related mortality $(12,13)$. GVHD is classified as either acute or chronic GVHD based on clinical characteristics. According to the clinical definitions, classic acute GVHD (aGVHD) develops within 100 days posttransplant with distinctive clinical features in the skin, gastrointestinal (GI) tract, or liver. However, manifestations of aGVHD can reoccur, persist, or present after day 100 posttransplant and is then classified as recurrent, persistent, or late onset aGVHD. Classical chronic GVHD is not limited to specific organ system and can present at any time after transplantation. The diagnosis of chronic GVHD is based on consensus criteria for each organ system involved. While some clinical features are diagnostic (e.g., bronchiolitis obliterans and sclerotic features of the skin), other manifestations require additional clinical and/or histological criteria to be fulfilled. Some patients may also present as an overlap syndrome with clinical features of both acute and chronic GVHD.

Scoring systems have been developed to grade the severity of aGVHD based on the involvement of skin, GI-tract, and liver; the Glucksberg scale (grading aGVHD from I to IV) or the International Bone Marrow Transplant Registry (grading from A to D) are most widely used (14). First-line treatment for grade II-IV aGVHD is high-dose steroids (15), and a complete response is observed in $20-40 \%$ of patients $(16,17)$. There is no consensus regarding the preferred therapy for steroid-refractory aGVHD; commonly utilized options include TNF $\alpha$ blockade,
anti-IL-6 antibodies, mTOR inhibitors, mycophenolate mofetil, and extracorporeal photopheresis (18). Despite several therapeutic alternatives, patients with grade IV steroid-refractory aGVHD have a dismal long-term prognosis (15).

Donor T cells play major roles in the development of aGVHD, but multiple factors contribute to the overall risk of severe aGVHD. The development of aGVHD is believed to be a threestep process each involving different subsets of immune cells (Figure 1) $(19,20)$. The first step is characterized by activation of the innate immune system; this results in a state of systemic inflammation prior to the introduction of donor $\mathrm{T}$ cells. The chemotherapy and/or radiation used in the conditioning therapy invoke tissue damage with release of pro-inflammatory cytokines, e.g., IL-6, TNF $\alpha$, IFN- $\gamma$, and IL-1. Damage to the GI barrier allows increased translocation of microorganisms from the gut microbiome, with subsequent increased levels of circulating lipopolysaccharide as well as molecules with pathogen- and damage-associated molecular patterns (PAMPs/DAMPs) (21). As a consequence, antigen-presenting cells (APC) secrete proinflammatory cytokines and present host as well as pathogen peptides on their major histocompatibility complex molecules. A reduction of pretransplant inflammation (e.g., through the use of reduced intensity conditioning, reduction of gut microbiome levels) and the presence of genetic factors associated with reduced inflammatory responses are associated with a reduced risk of GVHD and treatment-related mortality (22-24). Several other factors also influence the pretransplant pro-inflammatory state, e.g., pro-inflammatory metabolites, soluble adhesion molecules, and factors associated with altered endothelial cell functions with increased vascular permeability $(6,25-27)$.

The second step is characterized by alloreactive T-cell activation, proliferation, and differentiation as a response to the presentation of host antigens by host APC in a proinflammatory context. Stimulation of specific T helper cell subsets is thought to be important for the initiation of later cytotoxic T-cell-mediated tissue damage $(19,20)$. Th1 cells release interferon- $\gamma($ IFN- $\gamma$ ) at high levels and express the transcription factors STAT4 and STAT1/T-bet $(28,29)$. This Th1 polarization seems to be important for the development of aGVHD, especially in the GI tract (30). Additionally, Th2 cells characterized by expression of the transcription factor GATA-3 and secretion of anti-inflammatory cytokines IL-4, IL-10, and IL-13 (31) may also play a role in GVHD pathogenesis. The available studies of Th2 cells in GVHD have given conflicting results, but some studies have described an association between Th2 differentiation and pulmonary as well as skin involvement in aGVHD $(30,32,33)$. Th17 cells are characterized by the expression of the transcription factor ROR $\gamma \mathrm{t}$ and IL-17 secretion (34), and IL-17-secreting T cells are thought to be important for aGVHD severity (35) as well as for early transplant-related severe lung injury (36). Finally, T regulatory cells are a specialized Th subset characterized by expression of the transcription factor FOXP3 and high IL-2 receptor (CD25) expression. These cells play an important regulatory role by actively suppressing immune responses through their release of the anti-inflammatory cytokines IL-10, TGF- $\beta$, and IL-35 (37), and through direct interaction with other $\mathrm{T}$ cell subsets. Tregs are suppressed during GVHD, and resolution of GVHD is associated 
Development of a proinflammatory environment
T cell activation and

differentiation

\section{Immunological tissue damage}

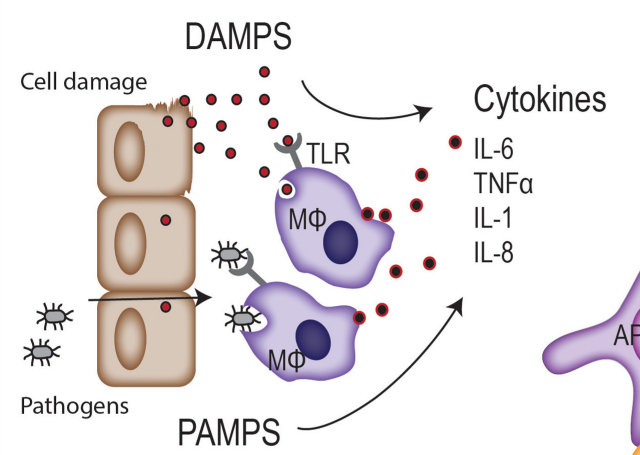

Lymph node

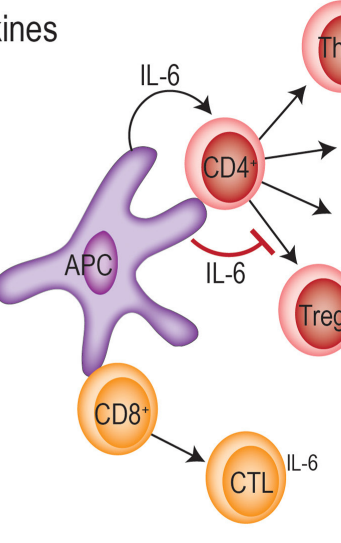

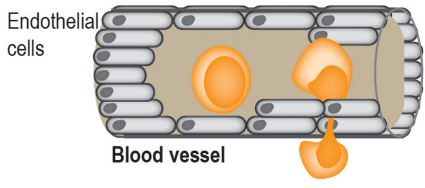

Increased extravasation
IL-17 Apoptotic

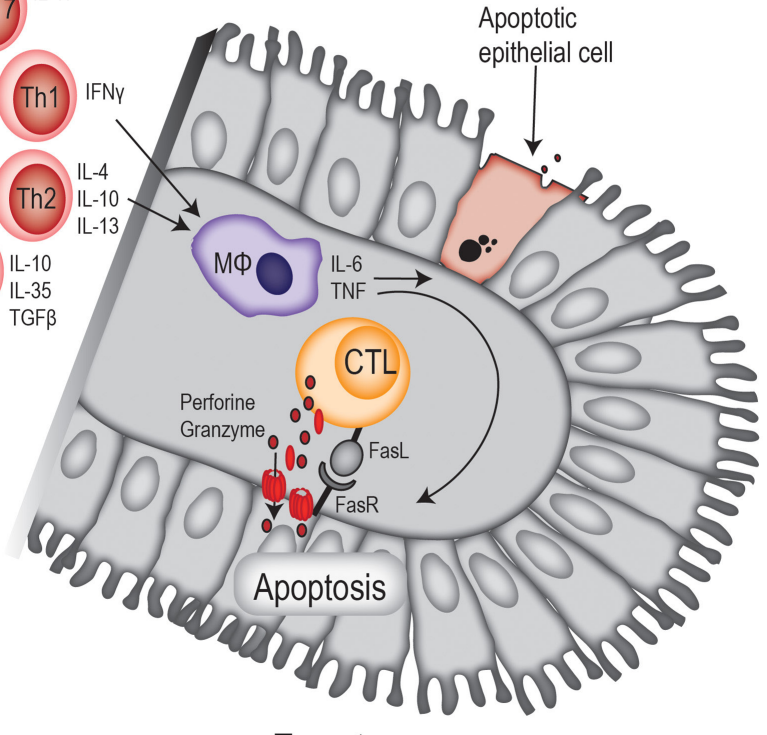

Target organ

e.g.: Intestinal epithelium

FIGURE 1 | A brief overview of acute GVHD pathogenesis. GVHD, graft-versus-host disease; DAMPS, danger-associated molecular patterns; PAMPS, pathogen-associated molecular patterns; APC, antigen-presenting cell; MФ: macrophage.

with restoration of the Treg function (38). Of particular interest, given the current topic of discussion, a majority of early posttransplant circulating TCR $\alpha \beta^{+} \mathrm{CD}^{+}$and $\mathrm{CD}^{+} \mathrm{T}$ cells release IL-6 at relatively high levels together with classical proinflammatory cytokines such as IFN- $\gamma$ and TNF $\alpha$ (39).

The third step of GVHD development is characterized by local action of cytotoxic $\mathrm{CD}^{+} \mathrm{T}$ cells triggered by the local release of chemokines during the two first steps; these cells mediate direct cytotoxic effects upon target cell recognition, including secretion of perforin/granzyme and FAS-ligand. Other T-cell subsets contribute to the organ-specific manifestations of GVHD through polarization of macrophages toward a pro-inflammatory (M1) phenotype that further increase tissue damage through the release of oxidants and pro-inflammatory cytokines including TNF- $\alpha$ and IL-6 $(40,41)$.

\section{IL-6 AND ITS RECEPTORS-CLASSICAL SIGNALING AND TRANS-SIGNALING}

\section{The Structure and Release of IL-6}

Interleukin-6 is a glycosylated protein with a molecular weight of $21-28 \mathrm{kDa}(42)$. The systemic (serum/plasma) levels usually range from 1.8 to $14 \mathrm{pg} / \mathrm{ml}$ in healthy individuals with no significant age-dependent differences $(43,44)$. During inflammation a more than $10^{5}$-fold increase can be observed, often correlating with disease severity (45). IL-6 is released predominantly by cells of mesenchymal origin, fibroblasts, muscle cells, keratinocytes, monocytes, and macrophages (46) but can also be released by endothelial cells. During acute inflammation the main transcription factors responsible for the increased IL-6 expression are NF- $\kappa$ B, CEBP- $\alpha$, and AP-1 (47-49); these are activated by $\mathrm{TNF} \alpha$, IL- $1 \beta$, the toll-receptor pathway, prostaglandins, and adipokines (50). IL-6 expression is also regulated by several miRNAs and RNases. Macrophages and monocytes appear to be the main sources of IL-6 during acute inflammation, while $\mathrm{T}$ cells seem to be a major contributor during chronic inflammation (51). However, IL-6 is also released in several physiological settings, e.g., during exercise when IL-6 released by muscle tissue can cause a 100 -fold increase in systemic levels (52).

\section{The IL-6 Receptor-Classical versus Trans-Signaling and IL-6 Cluster Signaling}

The IL- 6 receptor exists both in a membrane-bound and a soluble form; it has only a short intracellular domain and relies on the 
ubiquitously expressed gp130 cell membrane protein for intracellular signal transduction (10). The membrane-bound receptor is only expressed by a limited number of cell types, including hepatocytes, neutrophils, naïve T cells, macrophages, and a subset of intestinal epithelial cells. Thus, in these cells, IL-6R signaling can be initiated through the membrane-associated complex of IL-6, IL-6R, and gp130. This is termed classical signaling and is often associated with tissue regeneration and anti-inflammatory properties (10).

Most soluble cytokine receptors inactivate cytokines by interfering with membrane receptor binding, whereas the soluble IL-6R receptor in complex with IL- 6 binds and activates gp 130 on cells that do not express the membrane-bound IL-6R (mIL-6R). Thus, cells that do not express the IL-6R themselves can be IL-6 responsive; this mode of activation is called trans-signaling and seems important for many of the pro-inflammatory effects of IL-6 (Figure 2) (42).

Soluble IL-6R is mainly formed through cleavage of $\mathrm{mIL}-$ 6R by a disintegrin and metalloprotease (ADAM) 10 and 17 proteases. The soluble receptor is constitutively released by the liver and by hematopoietic cells, but activation of ADAM17 during inflammation causes a rapid local increase in sIL-6R levels.
Dimeric gp130 is produced by alternative splicing and is secreted into serum in a soluble form; this dimer cannot bind IL-6 alone but only IL-6 in complex with sIL-6R. Classical IL-6 signaling will then remain intact because of the free IL- 6 and unaffected membrane-bound IL-6R, whereas IL-6 trans-signaling is quenched due to the binding of the soluble IL-6/IL-6R dimeric complex. Under normal circumstances the sgp130 has a higher molar concentration than the sIL-6R (two times higher), and gp130 thereby acts as a physiological buffer against IL-6 transactivation. Thus, IL- 6 trans-signaling is regulated both by the release of the sIL-6R and the level of soluble gp130.

A third mode of IL- 6 signaling termed IL- 6 cluster signaling has recently been described (53). IL- 6 is then loaded onto the IL-6 receptor as an intracellular process and thereafter expressed on the cell surface membrane of APC where the complex directly stimulates gp130 on T cells by direct cell-cell contact (53). So far, cluster signaling has only been described for the development of pathogenic Th17 cells in mice.

\section{The IL-6 Cytokine Family}

The IL-6 family includes IL-11, IL-27, IL-31, leukemia inhibitory factor (LIF), OCM, ciliary neurotrophic factor (CNTF), CT-1, NP, CLC, CT-2, and humanin (Table 1). These proteins

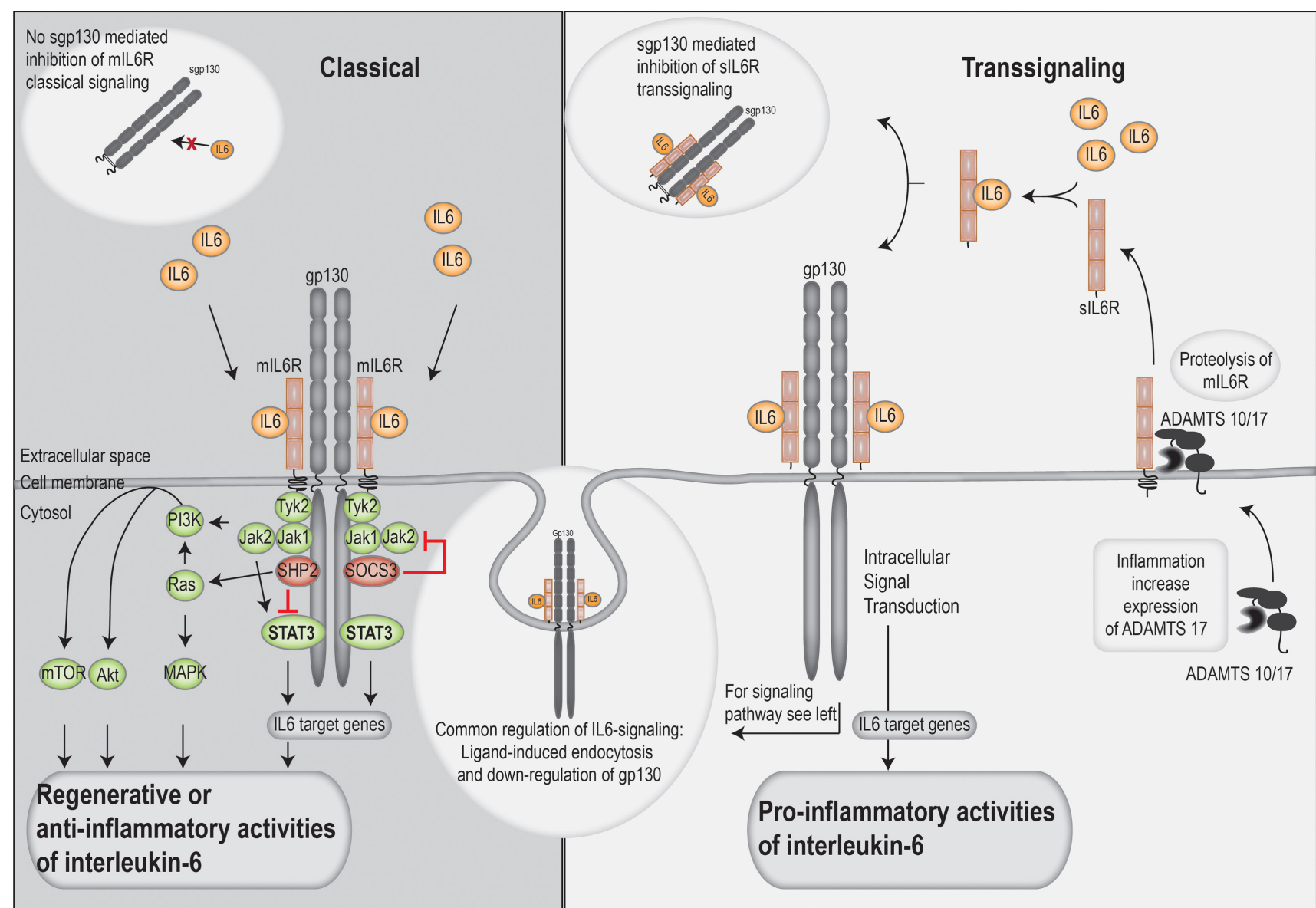

FIGURE 2 | An overview of the classical and trans-signaling. 
share structural resemblance with IL-6 and utilize gp130 or a gp130-like molecule for intracellular signal transduction (54). However, more ligand-specific receptor subunits are also used, including leukemia inhibitory factor receptor, OSMR, and IL-27RA. Some of these ligand-specific receptors have intracellular domains that can stimulate other signaling cascades than that of gp130. There is also cross-reactivity between the different IL-6 family cytokines and their receptors. Based on the different combinations of the utilized transmembrane proteins, the IL-6 cytokine family can be divided into different subgroups (Table 1) (55).

\section{Receptor-Initiated Intracellular Signal Transduction}

Gp130 is non-covalently associated with the Janus kinases (JAKs) JAK1, JAK2, and TYK2. Following receptor ligation, the JAKs are auto-phosphorylated, and they also phosphorylate gp130. This phosphorylation provides docking sites for phosphorylation of STAT1, STAT3, and the tyrosine phosphatase SHP-2. After phosphorylation, STAT3 dimerizes and is translocated to the nucleus where it acts as a transcription factor (56). Furthermore, SHP-2 activates the RAS/RAF/MAPK/ERK pathway, whereas gp130 activation also leads to activation of the PI3k-AKT pathway together with the transcriptional regulator YAP1 (Figure 2). Most of the IL-6 effects seem to be STAT3-mediated. STAT3 is controlled by a negative feedback mechanism; it induces expression of SOCS proteins and activation of the SHP-2 phosphatase. SOCS3 then binds with high affinity to the same phosphorylated binding site on gp130 as JAK1/2 and thereby inhibits further intracellular signaling. Even though SOCS1 can also bind to the same site, this interaction is believed to be functionally less important in vivo. IL-6 signaling is also inhibited by internalization and degradation of the receptor complex, and internalization of gp130 prevents further signaling of the IL- 6 cytokines.

TABLE 1 | The IL-6 cytokine family - an overview of the receptor ligands/ cytokines, their receptor structure, and the different subgroups based on receptor complex.

\begin{tabular}{lll}
\hline $\begin{array}{l}\text { Receptor } \\
\text { ligands }\end{array}$ & $\begin{array}{l}\text { Transmembrane signal } \\
\text { transducer }\end{array}$ & Different receptor complexes \\
\hline IL-6 & Dimeric gp130 & \\
IL-11 & & IL-6R + gp130 \\
IL-1R + gp130
\end{tabular}

IL-6, interleukin-6; LIF, leukemia inhibitory factor; LIFR, LIF receptor; OSMR, OSMreceptor; CNTF, ciliary neurotrophic factor; CNTFR, CNTF receptor; sCNTFR, soluble CNTF receptor; CT-1R, CT-1 receptor; WSX-1 alias:IL-27RA.

\section{Experimental Tools for Examining Classical IL-6 Signaling and Trans-Signaling}

The development of the two designer proteins sgp130FC and Hyper-IL-6 has made it possible to investigate the in vitro and in vivo effects of IL-6 classical and trans-signaling (42). The sgp130FC is constituted of two monomeric sgp130 molecules coupled with a human FC region. The affinity of sgp130FC to the IL-6/sIL-6 complex is 100- to 1,000-folds higher than naturally occurring sgp130 monomers, and it can abolish IL-6 trans-signaling without affecting the classical IL-6 signaling. The designer cytokines Hyper-IL- 6 consists of IL- 6 that is directly linked with the IL- 6 receptor. Hyper IL- 6 binds and activates gp130 on cells not expressing mIL- 6 receptor. The use of these molecules in several mouse models has given valuable insight into IL-6 biology, e.g., antigen-induced arthritis, inflammatory bowel disease, colitis associated cancer, pancreatitis induced acute lung injury, and hepatocellular carcinoma model (57-61).

\section{IL-6, THE ACUTE PHASE RESPONSE AND THE RISK OF GVHD}

The acute phase response represents a physiological increase in the levels of certain serum proteins due to increased production and release especially by the liver, and this includes C-reactive protein (CRP), serum amyloid $\mathrm{P}$, ferritin, mannose binding protein, and fibrinogen (62). IL-6 is the main driver of the response, but other cytokines (IL-1, IL-8/CXCL8, and TNF $\alpha$ ) also contribute (62). The levels of several acute phase proteins (e.g., CRP) is strongly correlated with IL-6 levels, and the IL-6 levels are again often correlated with the extent of tissue damage. In some malignancies there is evidence of chronic inflammation with a persisting acute phase response; but this response may also be due to constitutive IL- 6 release by malignant cells $(63,64)$.

Both IL- 6 and CRP levels are elevated in most patients prior to ASCT, and this maybe due to chronic fungal or bacterial infections, GI barrier break, or residual malignant disease $(65,66)$. The impact of pretransplant CRP levels after allotransplantation has been investigated in several studies (6, 65-71). Elevated CRP levels seem then to independently entail a higher transplant-related morality without increasing the risk of acute or chronic GVHD. The effect of both CRP and IL-6 levels has only been investigated in two studies $(6,66)$. Although CRP and IL-6 serum levels are highly correlated, CRP seems to independently influence the TRM, while the pretransplant IL-6 level does not seem to have a similar impact on TRM or GVHD. A possible explanation for this could be that the CRP levels are influenced by several comorbidities and not only IL-6.

\section{IL-6, EFFECTS ON IMMUNOCOMPETENT CELLS}

Interleukin-6 has both direct and indirect effects on immunocompetent cells involved in the development of GVHD. Several of these effects are summarized in Table 2. First, IL-6 is essential 
TABLE 2 | Important effects of interleukin-6 (IL-6) on immunocompetent cells involved graft-versus-host disease (GVHD) and on GVHD target organs.

\section{IL-6 effects on immunocompetent cells}

T cells: Membrane-bound IL-6R mainly expressed on naïve and memory T cells $(60,72)$.

Naïve T cells: IL-6 causes STAT3 activation, resulting in SOCS1 expression and thereby inhibited Th1 polarization (73).

Th1 cells: Suppressed Th1 development (73).

Th2 cells: Enhanced Th2/polarization/development through STAT3 dependent c-maf expression and STAT3 independent NFAT expression (73).

Th17 cells: Enhanced Th17 development through IL-6- and IL-21-induced STAT3 activation followed by increased ROR $\gamma$ T expression (56, 73-76). Differentiation from naïve T cells to Th17 relies largely on classical IL-6 signaling, whereas maintenance of Th17 cells depends on trans-signaling (60). STAT3 activation in naïve T cells by mIL-6R/IL-6 complex on the dendritic cells (cluster signaling) has been shown to be important for the development of pathogenic Th17 cells (53).

Th22 cells: The development depends on combined effects of IL-6, TNF $\alpha$, $\mathrm{IL}-1 \beta$, and the aryl hydrocarbon receptor (77).

Tregs: Suppressed Treg development, inhibition of FOXP3 expression. Indirect effects of IL-6 may increase Treg development through increased release of anti-inflammatory cytokines (78).

Tfh: IL-6 seems to commit T cells to Thf differentiation $(79,80)$.

\section{Dendritic cells and monocytes}

Dendritic cells: Inhibits differentiation of dendritic cell from bone marrow progenitors, and decreased responsiveness of dendritic cells. STAT3 activation seems important for these effects $(81,82)$.

Monocytes: Increased M-CSF expression favors differentiation into macrophages rather than dendritic cells (83).

B cells: A key factor for regulation of $B$ cell survival and maturation through both direct as well as indirect effects by stimulation of Tfh development $(79,80)$. Supports development into long-lived plasma cells (84).

Mesenchymal stem cells (MSCs): MSCs have unique immunomodulatory effects and have therefore been used in the treatment of acute and chronic GVHD. MSCs suppress Th1 and Th17 cells and induce Treg expansion through the release of multiple cytokines, including IL-6 and the IL-6 family cytokine LIF (85). Pro-inflammatory signals upregulate the constitutive IL-6 release by MSCs (86), and autocrine IL-6 stimulation will thereafter induce the release of immunosuppressive prostaglandin E2 by the MSCs (87). Furthermore, LIF secretion by MSCs inhibits T-cell proliferation in mixed lymphocyte reaction and seems to enhance the generation of Tregs (88). Autocrine IL-6 stimulation seems important for their survival, maintenance of stemness, and regulation of proliferation; ERK1/2 seems important for these effects $(89,90)$. MSC/T cell cross talk seems to increase local IL-6 levels (91).

\section{Effects of IL-6 on leukocyte migration during local inflammation}

- Enhances recruitment of primed T cells to inflamed tissue and entry of naïve T cells to lymphoid organs (54).

- Fever alone increases leukocyte extravasation through gp130 dependent mechanisms (92).

- IL-6 trans-signaling as well as signaling initiated by other IL-6 family members increase L-selectin expression by $T$ cells through ERK1/2 activation and increase their extravasation $(93,94)$

- IL-6 trans-signaling increases vascular expression of both adhesion the molecules (e.g., ICAM-1, VCAM-1, CD62E, and release of chemoattractant (CCL2, CXCL10, CCL4, CCL5, CCL11, and CCL17) (95).

for maturation, proliferation, differentiation, and maintenance of B cells/plasma cells and several proinflammatory T-cell subsets. IL-6 seems to enhance the development of pro-inflammatory Th17 and Th2 cell and to inhibit the development T regulatory cells. Second, IL-6-signaling is crucial for trafficking of immune cells to inflamed tissues and lymphoid organs. This is caused both by altered expression of adhesion molecules by endothelial cells and by expression of their ligands by immunocompetent cells. Third, IL-6 has important functions in GVHD target organs, and there may therefore be a risk of combined injury during GVHD (e.g., GVHD-induced immune-mediated damage, pharmacological toxicity, and IL-6 inhibition). Finally, IL-6 together with TNF- $\alpha$ released from macrophages has been reported to directly/ independently contribute to tissue damage in GVHD (40).

\section{IL-6 A REGULATOR OF STEM CELLS AND TISSUE REGENERATION}

Interleukin- 6 is important for the regulation of stem cells and tissue regeneration in several organs. This has been best demonstrated for hematopoiesis, liver cells, GI mucosa, and muscle cells. A complete overview of these effects is beyond the scope of this article. A brief overview of the major effects of IL- 6 in these different organ systems is given in Table 3. Impaired IL-6 function in these organs is associated with reduced regeneration after injury, and IL-6 dysregulation during chronic inflammation can contribute to organ dysfunction.

\section{THE ROLE OF IL-6 IN GVHD-LESSONS FROM ANIMAL MODELS}

The role of IL- 6 in acute and chronic GVHD has been investigated in several mouse models. Givon et al. (110) examined the effect of IL-6 on bone marrow reconstitution after syngeneic, semiallogenic, and ASCT and found that posttransplant treatment with subcutaneous recombinant IL-6 significantly supported white blood count reconstitution and improved survival in syngeneic as well as allogenic transplantation. This effect was only significant for animals transplanted with a low stem cell dose. In contrast, mice receiving IL- 6 showed increases in both the severity of and mortality from GVHD.

Chen et al. (111) observed increased systemic IL-6 and IL-6R levels early after both syngeneic and allogeneic transplantation. These levels returned to baseline over time in the syngeneic group, whereas IL-6 levels remained high in mice developing GVHD. Both IL-6 and IL-6R expression increased in the liver and colon (but were stable in the spleen), and the highest IL-6R mRNA levels were observed in these two organs. Selective IL-6 knockout in neither recipient nor donor cells was sufficient to protect from GVHD. However, GVHD treatment with anti-IL-6 resulted in significantly lower weight loss, less histopathological evidence of damage to colon, liver, and lungs, and significantly increased Treg levels in the spleen. The increased Treg levels were not dependent on an intact thymus; rather the IL- 6 blockade increased peripheral generation of Treg cells and reduced the levels of Th1 and Th17 cells. Similar results were shown by Noguchi et al. (112); treatment with an anti-IL-6 antibody reduced liver enzyme levels as well as the occurrence of organ failure and was associated with reduced infiltration of Th1 and Th17 cells, increased Treg cells, and improved survival. 
TABLE 3 | Important effects of interleukin-6 (IL-6) in target organs of graft-versus-host disease (GVHD) and on metabolism.

\section{IL-6 and the target organs of GVHD}

Liver: IL-6 together with other cytokines is important for liver regeneration; the prolonged effect of trans-stimulation seems more important than classical signaling $(96,97)$. Clinical IL-6 inhibition can cause increased liver transaminases (98), but it is not known whether IL-6 targeting, potentially liver-toxic drugs and concomitant immune-mediated injury due to GVHD, will increase the risk of severe liver toxicity in allotransplant recipients.

Gastrointestinal mucosa: IL-6/STAT3 is important for regeneration of intestinal epithelium, maintain barrier integrity, ensure adequate secretion of antimicrobial peptide, support proliferation, and facilitate migration of intraepithelial lymphocytes (99-101). Inhibition of IL-6 signaling (especially trans-activation) suppresses colitis $(59,102)$. Clinical use of IL-6 inhibition is associated with increased risk of bowel perforation (103).

\section{IL-6 and the effects on metabolism}

Cachexia: High IL-6 levels are often observed in patients with cachexia. Although some studies have shown that IL-6 blockade can attenuate anemia and muscle loss in cancer patients, the role of IL-6 in the metabolic changes during cachexia is still unclear.

Glucose tolerance: Obesity/glucose intolerance is associated with low-grade chronic inflammation and high baseline IL-6 levels (104). Insulin treatment reduces IL-6 levels $(105,106)$. IL-6 secreted by adipocytes seems to favor the development of anti-inflammatory M2 (107). Inhibition of the mIL-6R in the liver is associated with reduced glucose tolerance and dyslipidemia (108).

Muscle cells: IL-6 is important in regeneration of muscle after injury through a direct effect on muscle stem cell-IL-6 (109). IL-6 is also actively secreted by muscle cells and has important endocrine and metabolic effects.

Tawara et al. (113) investigated the effect of IL-6 derived from donor $\mathrm{T}$ cells. In contrast to the findings by Chen et al., selective IL-6 knockout in donor/graft T cells was associated with less severe GVHD and prolonged survival. Pretransplant anti-IL-6 treatment also significantly improved survival and clinical as well as histopathological severity of GVHD, but the Treg levels were not altered. Importantly, the GVL effect was maintained despite the reduction in GVHD. The systemic cytokine levels and the levels of circulating cells were not altered by the treatment, and selective ablation of IL-6 in recipient bone marrow cells did not reduce the occurrence or severity of GVHD.

Organ-specific effects of IL-6 in GVHD have been investigated in two different mouse models. Varelias et al. (36) examined the role of IL-6 in idiopathic pulmonary syndrome (IPS) after ASCT and demonstrated that local secretion of IL- 6 induced Th17 cell differentiation that was necessary for disease development. IPS development could be prevented by IL-17 knockout or by the use of neutralizing antibodies against IL-17. In a second study, Le Huu et al. (114) investigated the role of IL-6 in a sclerodermous cGVHD model and observed that IL-6 levels increased during disease progression. Treatment with IL-6-neutralizing antibodies prior to manifestations of scleroderma significantly decreased disease severity, while no reduction was observed when IL-6 neutralization was started after the onset of cGVHD. Treatment with anti-IL-6 was associated with a significant increase in the number of splenic Treg cells, whereas the expression of IFN- $\gamma$, TNF $\alpha$, IL-6, IL-18, TGF- $\beta 1$, CCL2, CCL3, and CCL5 in affected skin was significantly reduced.
TABLE 4 | The role of STAT3 in regulation of activation and differentiation of immune cells in allogeneic stem cell transplantation; important observations in animal studies and experimental in vitro studies.

Pretransplant intervention: Pretransplant inhibition of STAT3 in graft T cells through upstream pharmacological JAK2 inhibition reduced graft-versus-host disease (GVHD) mortality and increased the levels of Tregs (116).

GVHD mortality: STAT3 ablation reduces posttransplant mortality as well as the severity of both acute and chronic GVHD, especially GVHD severity in the skin and colon (119, 120).

Tolerance induction: JAK2 inhibition seems to be more effective than interleukin-6 (IL-6) neutralization for induction of immunological tolerance $(117,118)$.

T cell proliferation: Proliferating alloreactive T cells expressed higher levels of phosphorylated STAT3 compared to proliferating T cells in syngeneic transplantations (116)

Dendritic cells: Pharmacological inhibition of STAT3 phosphorylation by IL-6 neutralizing antibodies or JAK2 inhibitors does not inhibit dendritic cells (117).

Regulatory T cells: Equal numbers of Treg cells are observed in both STAT3-wt and knockout mice after syngenic transplantation, while after allotransplantation mice STAT3 expression is associated with a lower number of Tregs cells (119).

The STAT3 effects differ between nTregs and iTregs; nTregs with impaired STAT3 function do not prevent GVHD, whereas STAT3 knockdown in iTreg prevents GVHD (119).

\section{EXPERIMENTAL STUDIES SUGGEST A ROLE OF JAK2-STAT3 ACTIVATION IN ALLORECOGNITION AND GVHD DEVELOPMENT}

The role of STAT3 in the regulation of activation and differentiation of Tregs and Th17 cells after allotransplantation has been investigated in several mouse models (i.e., STAT3-knockout mice) and in vitro models. Emerging evidence also suggests that activation of STATs in B cells is also important for GVHD (115). A complete review of this scientific field is beyond the scope of this article, but an overview of important observations is given in Table 4 (116-120). In summary, these reports suggest that targeting of IL-6/JAK2/STAT3 signaling can be effective against the development of GVHD. Treatment can be given either by graft engineering or as posttransplant therapy, the function of several immunocompetent cells will then be affected, and reduced GVHD severity as well as improved survival has been observed. Based on these findings, treatment with the JAK1/2 inhibitor ruxolitinib has been tested in patients with manifest chronic and aGVHD, and it was reported to improve GVHD and reduce serum cytokine levels $(121,122)$. Patients included in these two studies are heterogeneous with respect to GVHD manifestations, previously GVHD prophylaxis and treatment. Further welldesigned studies are definitely needed to determine the efficacy and toxicity of JAK2/STAT3 blockade in allotransplant recipients.

\section{IL-6 IN ASCT - CLINICAL DATA}

\section{aGVHD and IL-6 Polymorphism}

Specific single nucleotide polymorphisms (SNPs) in the IL-6R and the IL- 6 gene are associated with higher serum levels of IL-6 and sIL-6R. Especially the SNP 174 G < C (rs1800795) in the 
IL-6 promoter region affects the transcription and secretion of IL- 6 and has been associated with several autoimmune disorders $(123,124)$. A summary of the 10 studies that have examined the role of this specific SNP in acute and chronic GVHD is presented in Table 5; of note, only one of those studies examined effects of SNPs both in the IL-6 and IL-6R gene (125-137). A metaanalysis of seven studies published during the period 2001-2012 was performed by Choi et al. (138); they concluded that patients who received grafts from donors either hetero- or homozygous for the IL-6 G allele had significantly increased risk of developing aGVHD grade I-IV (odds ratio 3.30) or grade II-IV (odds ratio 1.73). To date, the largest study investigating the role of IL-6 polymorphisms in GVHD is that of Chien et al. (128), which included 1,298 patients. They investigated IL-6 SNP polymorphisms together with 14 other candidate genes, and their unadjusted and adjusted analyses of patients with unrelated donors showed that the donor genotype rs 1800795 was associated with a $20-50 \%$ increased risk of grade II-IV aGVHD.

Kim et al. $(129,130)$ investigated the effects of 259 different SNPs on outcome after ASCT. While they did not observe any effect of SNPs in the IL-6 gene, patients with an SNP in the IL-6R gene ( $r$ 4845617) showed decreased relapse-free survival. In a new study of the same patients, univariate analysis identified several SNPs in the IL-6R (rs2229238, rs4072391, rs4379670, and rs7514452) that were associated with an increased risk of aGVHD, but they could not predict aGVHD in a multivariate analysis. The SNP (rs4845617) was predictive of cGVHD of the eyes and could be included in a model to predict GVHD.

The IL-6 receptor Asp358Ala SNP (rs2228145) increases the proteolytic conversion rates by ADAM proteases, and this leads to higher soluble IL-6R levels; it is also associated with a lower baseline CRP and decreased incidence of autoimmune disorders (139). To the best of our knowledge, the effect of this specific SNP on the risk of complications after allotransplantation has not been investigated.

\section{IL-6 Level and Clinical Outcome}

Pretransplant IL-6 levels in allotransplant recipients show a wide variation and a strong correlation with pretransplant CRP levels but do not seem to predict survival, risk of GVHD, or non-relapse mortality after transplantation (6). This study included only patients with related donors (mainly matched sibling donors) transplanted in complete remission (all except 1 of the 99 patients), and the pretransplant systemic levels of all IL-6 family members were studied. Only pretransplant IL-31 influenced late transplant-related mortality. However, there was a significant association between pretransplant IL-6 and early postconditioning weight gain (i.e., fluid retention), and this fluid retention in turn was a risk factor for aGVHD, transplant-related mortality, and overall survival. The authors concluded that pretransplant CRP, pretransplant IL-31, and early posttransplant fluid retention were independent risk factors for transplant-related mortality and survival after allotransplantation. The strong association between pretransplant IL-6 levels and vascular permeability/fluid retention suggests that effects of IL-6 on endothelial cells may contribute to a high-risk phenotype.

After onset of chemotherapy, IL-6 levels rise significantly and reach a maximum during the two first weeks before returning to baseline in most patients $(140,141)$. Increased systemic IL-6 levels are also observed during febrile illnesses and toxic complications in patients with hematological malignancies. Both after intensive chemotherapy and allotransplantation, the levels are

TABLE 5 | Summary of studies investigating the influence of different SNPs in the IL-6 and IL-6R on outcome after allogenic stem cell transplantation.

\begin{tabular}{|c|c|c|c|c|c|c|c|c|c|}
\hline \multirow[t]{2}{*}{ Reference } & \multirow[t]{2}{*}{ Year } & \multirow[t]{2}{*}{ Patients } & \multirow[t]{2}{*}{ Donor type } & \multicolumn{2}{|c|}{$\begin{array}{l}\text { Stem cell } \\
\text { source }\end{array}$} & \multicolumn{2}{|c|}{ AGVHD } & \multirow[t]{2}{*}{ cGVHD } & \multirow[t]{2}{*}{ Survival } \\
\hline & & & & PB & BM & Genotype & Risk & & \\
\hline Alam et al. (133) & 2015 & 268 & MRD 184 & 184 & NR & $\mathrm{D}$ & Increased & NR & No effect \\
\hline Chien et al. (128) & 2012 & 1,298 & $\begin{array}{l}\text { Related } 612 \\
\text { Unrelated } 686\end{array}$ & 377 & 921 & $\mathrm{D}$ & Increased & NR & NR \\
\hline Karabon et al. (134) & 2005 & 93 & Sibling & $N R$ & $N R$ & $\mathrm{D} / \mathrm{R}$ & Increased & NR & No \\
\hline Laguila Visentainer et al. (131) & 2005 & 118 & Sibling & 36 & 82 & & No effect & Increased & No effect \\
\hline Mullighan et al. (137) & 2004 & 160 & 154 sibling & 100 & 60 & $\mathrm{D}$ & Increased & No & No effect \\
\hline Lin et al. (132) & 2003 & 993 & Sibling & & & & No effect & NR & NR \\
\hline Rocha et al. (136) & 2002 & 107 & Sibling & & 107 & & No effect & No effect & No effect \\
\hline Kim et al. $(129,130)$ & 2012,2014 & 394 & MRD 288 & 276 & 118 & \multicolumn{4}{|c|}{ Increased risk chronic eye GVHD } \\
\hline & & & MMD19 & & & \multirow{2}{*}{\multicolumn{4}{|c|}{ Recipient genotype associated with increased NRM }} \\
\hline & & & MUD84 & & & & & & \\
\hline
\end{tabular}

BM, bone marrow; $D$, donor; MMD, mismatched related donor; MRD, matched related donor; MUD, matched unrelated donor; NR, not reported; NRM, non-relapse mortality; PB, peripheral blood stem cell collection; R, recipient; aGVHD, acute GVHD; SNPs, single nucleotide polymorphisms; GVHD, graft-versus-host disease. 
strongly associated with the CRP levels and are accompanied by a decrease in sIL-6R levels (142-144). Conflicting results have been reported about IL-6 levels in aGVHD; some have reported high levels prior to aGVHD $(36,145,146)$, whereas others have not been able to verify this (147-149). Increased IL-6 levels have also been associated with severe pulmonary toxicity and with reduced survival after autologous stem cell transplantation $(140,150)$.

\section{IL-6 Blockade in Prevention of GVHD}

Only two drugs inhibiting IL-6 or the IL-6R are currently approved for clinical use; tocilizumab is used in rheumatoid arthritis and systemic sclerosis, whereas siltuximab is approved for treatment of multicentric Castleman's disease (Table 6). Tocilizumab is a humanized monoclonal antibody that binds to both membrane-bound and soluble IL-6R, while siltuximab is a chimeric monoclonal antibody binding circulating IL-6 (151). Tocilizumab is generally well tolerated in patients with rheumatoid arthritis; the most commonly reported side effects being dyslipidemia (21-25\%), increased liver transaminases (5-6\%), and transient decreases in neutrophil counts (152-154). IL- 6 blockade inhibits the acute phase response and may thereby mask signs of acute severe infections. Although some studies in rheumatoid arthritis have shown a higher rate of infections in patients treated with tocilizumab $(153,154)$, this could not be confirmed in a large multicenter study (152). Several other IL-6 inhibitory small molecules and monoclonal antibodies are currently in clinical trials both for autoimmune disorders and different types of cancer (151).

IL-6 blockade as prophylaxis against GVHD has been investigated in only one study (155), where a single dose of tocilizumab $8 \mathrm{mg} / \mathrm{kg}$ (maximum dose $800 \mathrm{mg}$ ) was added to standard GVHD prophylaxis with cyclosporine A and methotrexate in 48 patients that underwent $\mathrm{T}$-cell replete allotransplantation with myeloablative or reduced intensity conditioning regimes. The incidence of grade III-IV aGVHD and the non-relapse mortality were only $4 \%$. The incidence of severe aGVHD was also low in patients receiving myeloablative conditioning based on total body irradiation; a treatment protocol usually associated with a high risk of GVHD. The addition of tocilizumab appeared generally safe with no increase in graft rejections, time to neutrophil

TABLE 6 | A comparison of the two IL-6 blocking monoclonal antibodies approved for clinical use.

\begin{tabular}{|c|c|c|}
\hline Characteristics & Tocilicumab & Siltuximab \\
\hline Specificity & Anti IL-6R (membrane and soluble) & Anti IL-6 \\
\hline Antibody structure & Humanized & $\begin{array}{l}\text { Chimeric } \\
\text { (mouse/human) }\end{array}$ \\
\hline Administration & Subcutaneous or intravenous & Intravenous \\
\hline Approved indications & $\begin{array}{l}\text { Rheumatoid arthritis } \\
\text { Systemic juvenile idiopathic arthritis }\end{array}$ & $\begin{array}{l}\text { HIV-negative } \\
\text { muticentric } \\
\text { Castleman's } \\
\text { disease }\end{array}$ \\
\hline $\begin{array}{l}\text { Example of reported } \\
\text { off-label use }\end{array}$ & $\begin{array}{l}\text { Cytokine release syndrome after } \\
\text { CAR-T therapy } \\
\text { Giant cell arteritis } \\
\text { Graft-versus-host disease } \\
\text { Adult Still's disease }\end{array}$ & \\
\hline
\end{tabular}

regeneration, chimerism at day +40 posttransplant, or early relapse compared to historical controls. Only three patients experienced severe liver toxicity during the first month after transplantation.

To our knowledge, there is only one ongoing trial that investigates the role of adding IL- 6 blockade to standard prophylactic GVHD-therapy (NCT02206035). In this open label phase II trial, tocilizumab is given in addition to tacrolimus/methotrexate and compared with a contemporary control cohort. The primary endpoint is grade II-IV GVHD during the first 180 days posttransplant. In a second trial, the rate of cytokines release syndrome with and without IL-6 blockade with tocilizumab will be investigated in a small number of patients receiving haploidentical transplantation with posttransplantation cyclophosphamide (NCT02057770).

\section{IL-6 Blockade in the Treatment of GVHD}

In addition to a few case reports (156-158) and conference abstracts (159) only two published case series report the effects of tocilizumab in the treatment of acute steroid-refractory aGVHD (Table 7) $(160,161)$. Drobyski et al. (161) described the effects in eight patients (two acute and two chronic GVHD) where tocilizumab was administered once every 3-4 weeks. Five patients had grade IV GVHD (four gut and one skin involvement), while one patient had grade II gut, and the last patient had grade III liver affection. One of these patients died early after tocilizumab administration and was not evaluable, one patient did not respond, three patients were classified as partial responders, and two patients were considered complete responders. In one of the patients with partial response, the treatment was discontinued because one could not exclude the possibility that tocilizumab worsened preexisting hyperbilirubinemia. A transient increase in liver transaminases was also observed in several patients. The authors concluded that infections were responsible for the major adverse events associated with tocilizumab administration, with a total of 13 documented infections.

Roddy et al. (160) reported the effect of tocilizumab in patients with steroid-refractory aGVHD; seven patients with grade IV and two with grade III aGVHD. Tocilizumab was administered in a similar manner as in the previously reported study. Five patients were classified as non-responders, two patients were classified as complete responder, and two patients had mixed response with persistence of severe aGVHD in one organ but resolved disease in other organs. In this study, four patients suffered from infectious episodes with two deaths being reported, but no liver toxicity was observed. Only one ongoing study for treatment of steroid-refractory aGVHD has been registered (https://clinicaltrials.gov, NCT01475162), but this study was ended because the risks of toxicity seemed to outweigh the potential benefits.

\section{CONCLUDING REMARKS}

Graft-versus-host disease is a complex, multi-systemic disease in which local and systemic factors play a role in orchestrating inflammation, tissue repair, and regeneration. The impact of SNPs in the IL-6 gene on GVHD risk indicates that IL-6 plays 
TABLE 7 | Summary of studies with IL-6 receptor (tocilizumab) or JAK2 (ruxolitinib) blockade in treatment of chronic and acute steroid-refractory GVHD.

\begin{tabular}{|c|c|c|c|c|c|c|c|c|}
\hline \multirow[t]{2}{*}{ Reference } & \multirow[t]{2}{*}{ Patients $(n)$} & \multirow[t]{2}{*}{ aGVHD $(n)$} & \multirow[t]{2}{*}{ cGVHD (n) } & \multicolumn{3}{|c|}{ Organ involvement (patients) } & \multirow[t]{2}{*}{ Response aGVHD } & \multirow[t]{2}{*}{ Response cGVHD } \\
\hline & & & & Skin & Gastrointestinal & Liver & & \\
\hline \multicolumn{9}{|l|}{ Tocilizumab } \\
\hline Drobyski et al. (161) & 8 & 6 & 2 & $\begin{array}{l}\text { Grade II: } 3 \\
\text { Grade IV: } 1\end{array}$ & $\begin{array}{l}\text { Grade II: } 1 \\
\text { Grade III: } 4\end{array}$ & Grade III: 1 & $\mathrm{CR} 2, \mathrm{PR} 2, \mathrm{NR} 1, \mathrm{NR} 1$ & 11 Stabilization 1 PR \\
\hline Roddy et al. (160) & 9 & 9 & 0 & Grade II: 1 & $\begin{array}{l}\text { Grade I: } 1 \\
\text { Grade II: } 2 \\
\text { Grade III: } 2 \\
\text { Grade IV: } 4\end{array}$ & $\begin{array}{l}\text { Grade I: } 1 \\
\text { Grade II: } 2 \\
\text { Grade III: } 1 \\
\text { Grade IV: } 2\end{array}$ & $\begin{array}{l}\text { CR: } 2, \text { CR in single } \\
\text { organ system } 2\end{array}$ & N/A \\
\hline Ganetsky et al. (159) & 5 & 5 & & All patients & Glücksberg grade IV & & CR 5 & N/A \\
\hline \multicolumn{9}{|l|}{ Ruxolitinib } \\
\hline Zeiser et al. (122) & 95 & 54 & 41 & All patients with aGV & $\begin{array}{l}\text { HD grade III/IV, not ot } \\
\text { specified }\end{array}$ & therwise & ORR 44, CR 25 & 35 \\
\hline Spoerl et al. (121) & 6 & 4 & 2 & Grade III: 2, Grade IV: 1 & Grade IV: 2 & Grade III: 1 & CR 1, PR 3 & 2 \\
\hline
\end{tabular}

CR, complete response; PR, partial response; NR, non-response; ORR, overall response rate; N/A, not applicable; GVHD, graft-versus-host disease; aGVHD, acute GVHD.

a role during early GVHD development. Blockade of the proinflammatory effects of IL-6 seems to be a possible therapeutic strategy since IL-6 and STAT3 activation are closely linked to the development of both Th17 and Treg cells, and since early STAT3 phosphorylation posttransplant seems to precede development of GVHD (118). However, currently available clinical data indicate that IL-6 blockade is most effective when used as GVHD prophylaxis, whereas manifest GVHD might be less susceptible to IL-6 blockade. An unselective systemic blockade of IL-6 is probably not without caveats, given the physiological importance of IL-6 in tissue regeneration and homeostasis in both the liver and GI tract, two organs commonly affected both in acute and chronic GVHD.

Most of the pro-inflammatory effects of IL- 6 seem to be caused by trans-signaling. A fusion protein consisting of the immunoglobulin Fc region and gp130 can be used for specific blocking of trans-signaling (56); this protein binds IL-6 in complex with sIL-6R but cannot bind free IL-6. Treatment with this selective inhibitor inhibits inflammation and preserves the regenerative

\section{REFERENCES}

1. Passweg JR, Baldomero H, Bader P, Bonini C, Cesaro S, Dreger P, et al. Impact of drug development on the use of stem cell transplantation: a report by the European Society for Blood and Marrow Transplantation (EBMT). Bone Marrow Transplant (2016) 52:191-6. doi:10.1038/bmt.2016.258

2. Passweg JR, Baldomero H, Bader P, Bonini C, Cesaro S, Dreger P, et al. Hematopoietic stem cell transplantation in Europe 2014: more than 40000 transplants annually. Bone Marrow Transplant (2016) 51(6):786-92. doi:10.1038/bmt.2016.20

3. Singh AK, McGuirk JP. Allogeneic stem cell transplantation: a historical and scientific overview. Cancer Res (2016) 76:6445-51. doi:10.1158/0008-5472. CAN-16-1311

4. Zeiser R, Socie G, Blazar BR. Pathogenesis of acute graft-versus-host disease: from intestinal microbiota alterations to donor $\mathrm{T}$ cell activation. $\mathrm{Br}$ J Haematol (2016) 175(2):191-207. doi:10.1111/bjh.14295

5. Lamarthée B, Malard F, Saas P, Mohty M, Gaugler B. Interleukin-22 in graftversus-host disease after allogeneic stem cell transplantation. Front Immunol (2016) 7:148. doi:10.3389/fimmu.2016.00148

6. Tvedt TH, Lie SA, Reikvam H, Rye KP, Lindås R, Gedde-Dahl T, et al. Pretransplant levels of CRP and interleukin- 6 family cytokines; effects on effects of IL-6 in mouse models of a wide variety of diseases, e.g., ulcerative colitis, rheumatoid arthritis, and acute pancreatitisassociated lung injury (56). All experimental models of GVHD explored so far have utilized either genetic or pharmacological blocking of IL-6, and little is therefore known about the relative contributions of trans- versus cis-/classical IL- 6 signaling in these settings. Further models should therefore address the use of selective blockade of IL-6 trans-signaling after ASCT.

\section{AUTHOR CONTRIBUTIONS}

TT, EE, AT, and ØB contributed equally to this work.

\section{FUNDING}

The authors received financial support for the Norwegian Cancer Society, Helse-Vest (grant no. 911946), the University of Bergen, Eivind Møllbach Pedersens Foundation, and The Family Blix Foundation.

outcome after allogeneic stem cell transplantation. Int J Mol Sci (2016) 17(11). doi:10.3390/ijms17111823

7. Kaly L, Rosner I. Tocilizumab - a novel therapy for non-organ-specific autoimmune diseases. Best Pract Res Clin Rheumatol (2012) 26(1):157-65. doi:10.1016/j.berh.2012.01.001

8. Jordan SC, Choi J, Kim I, Wu G, Toyoda M, Shin B, et al. Interleukin-6, a cytokine critical to mediation of inflammation, autoimmunity and allograft rejection: therapeutic implications of IL-6 receptor blockade. Transplantation (2017) 101(1):32-44. doi:10.1097/TP.0000000000001452

9. Kim GW, Lee NR, Pi RH, Lim YS, Lee YM, Lee JM, et al. IL-6 inhibitors for treatment of rheumatoid arthritis: past, present, and future. Arch Pharm Res (2015) 38(5):575-84. doi:10.1007/s12272-015-0569-8

10. Scheller J, Garbers C, Rose-John S. Interleukin-6: from basic biology to selective blockade of pro-inflammatory activities. Semin Immunol (2014) 26(1):2-12. doi:10.1016/j.smim.2013.11.002

11. Ho LJ, Luo SF, Lai JH. Biological effects of interleukin-6: clinical applications in autoimmune diseases and cancers. Biochem Pharmacol (2015) 97(1):16-26. doi:10.1016/j.bcp.2015.06.009

12. Lee SE, Cho BS, Kim JH, Yoon JH, Shin SH, Yahng SA, et al. Risk and prognostic factors for acute GVHD based on NIH consensus criteria. Bone Marrow Transplant (2013) 48(4):587-92. doi:10.1038/bmt.2012.187 
13. Jagasia M, Arora M, Flowers ME, Chao NJ, McCarthy PL, Cutler CS, et al. Risk factors for acute GVHD and survival after hematopoietic cell transplantation. Blood (2012) 119(1):296-307. doi:10.1182/blood-2011-06364265

14. Glucksberg H, Storb R, Fefer A, Buckner CD, Neiman PE, Clift RA, et al. Clinical manifestations of graft-versus-host disease in human recipients of marrow from HL-A-matched sibling donors. Transplantation (1974) 18(4):295-304. doi:10.1097/00007890-197410000-00001

15. Dignan FL, Clark A, Amrolia P, Cornish J, Jackson G, Mahendra P, et al. Diagnosis and management of acute graft-versus-host disease. Br J Haematol (2012) 158(1):30-45. doi:10.1111/j.1365-2141.2012.09129.x

16. MacMillan ML, Weisdorf DJ, Wagner JE, DeFor TE, Burns LJ, Ramsay NK, et al. Response of 443 patients to steroids as primary therapy for acute graftversus-host disease: comparison of grading systems. Biol Blood Marrow Transplant (2002) 8(7):387-94. doi:10.1053/bbmt.2002.v8.pm12171485

17. Hings IM, Severson R, Filipovich AH, Blazar BR, Kersey JH, Ramsay NK, et al. Treatment of moderate and severe acute GVHD after allogeneic bone marrow transplantation. Transplantation (1994) 58(4):437-42. doi:10.1097/ 00007890-199408270-00008

18. Bruserud $\varnothing$, Tvedt TH, Paulsen PQ, Ahmed AB, Gedde-DahlT, Tjønnfjord GE, et al. Extracorporeal photopheresis (photochemotherapy) in the treatment of acute and chronic graft versus host disease: immunological mechanisms and the results from clinical studies. Cancer Immunol Immunother (2014) 63(8):757-77. doi:10.1007/s00262-014-1578-Z

19. Ferrara JL, Levine JE, Reddy P, Holler E. Graft-versus-host disease. Lancet (2009) 373(9674):1550-61. doi:10.1016/S0140-6736(09)60237-3

20. Ferrara JL, Reddy P. Pathophysiology of graft-versus-host disease. Semin Hematol (2006) 43(1):3-10. doi:10.1053/j.seminhematol.2005.09.001

21. Toubai T, Mathewson ND, Magenau J, Reddy P. Danger signals and graftversus-host disease: current understanding and future perspectives. Front Immunol (2016) 7:539. doi:10.3389/fimmu.2016.00539

22. Beelen DW, Elmaagacli A, Müller KD, Hirche H, Schaefer UW. Influence of intestinal bacterial decontamination using metronidazole and ciprofloxacin or ciprofloxacin alone on the development of acute graft-versus-host disease after marrow transplantation in patients with hematologic malignancies: final results and long-term follow-up of an open-label prospective randomized trial. Blood (1999) 93(10):3267-75.

23. Guthery SL, Heubi JE, Filipovich A. Enteral metronidazole for the prevention of graft versus host disease in pediatric marrow transplant recipients: results of a pilot study. Bone Marrow Transplant (2004) 33(12):1235-9. doi:10.1038/sj. bmt. 1704474

24. Mielcarek M, Burroughs L, Leisenring W, Diaconescu R, Martin PJ, Sandmaier BM, et al. Prognostic relevance of 'early-onset' graft-versus-host disease following non-myeloablative haematopoietic cell transplantation. Br J Haematol (2005) 129(3):381-91. doi:10.1111/j.1365-2141.2005.05458.x

25. Lindås R, Tvedt TH, Hatfield KJ, Reikvam H, Bruserud O. Preconditioning serum levels of endothelial cell-derived molecules and the risk of posttransplant complications in patients treated with allogeneic stem cell transplantation. J Transplant (2014) 2014:404096. doi:10.1155/2014/ 404096

26. Reikvam H, Grønningsæter IS, Ahmed AB, Hatfield K, Bruserud $\varnothing$. Metabolic serum profiles for patients receiving allogeneic stem cell transplantation: the pretransplant profile differs for patients with and without posttransplant capillary leak syndrome. Dis Markers (2015) 2015:943430. doi:10.1155/2015/943430

27. Reikvam H, Hatfield K, Bruserud O. The pretransplant systemic metabolic profile reflects a risk of acute graft versus host disease after allogeneic stem cell transplantation. Metabolomics (2016) 12(1):12. doi:10.1007/ s11306-015-0880-x

28. Nishikomori R, Usui T, Wu CY, Morinobu A, O'Shea JJ, Strober W. Activated STAT4 has an essential role in Th1 differentiation and proliferation that is independent of its role in the maintenance of IL-12R beta 2 chain expression and signaling. J Immunol (2002) 169(8):4388-98. doi:10.4049/ jimmunol.169.8.4388

29. Mullen AC, High FA, Hutchins AS, Lee HW, Villarino AV, Livingston DM, et al. Role of T-bet in commitment of TH1 cells before IL-12-dependent selection. Science (2001) 292(5523):1907-10. doi:10.1126/science.1059835

30. Burman AC, Banovic T, Kuns RD, Clouston AD, Stanley AC, Morris ES, et al. IFNgamma differentially controls the development of idiopathic pneumonia syndrome and GVHD of the gastrointestinal tract. Blood (2007) 110(3):1064-72. doi:10.1182/blood-2006-12-063982

31. Zhu J, Yamane H, Cote-Sierra J, Guo L, Paul WE. GATA-3 promotes Th2 responses through three different mechanisms: induction of Th2 cytokine production, selective growth of Th2 cells and inhibition of Th1 cell-specific factors. Cell Res (2006) 16(1):3-10. doi:10.1038/sj.cr.7310002

32. Yi T, Chen Y, Wang L, Du G, Huang D, Zhao D, et al. Reciprocal differentiation and tissue-specific pathogenesis of Th1, Th2, and Th17 cells in graft-versus-host disease. Blood (2009) 114(14):3101-12. doi:10.1182/ blood-2009-05-219402

33. Nikolic B, Lee S, Bronson RT, Grusby MJ, Sykes M. Th1 and Th2 mediate acute graft-versus-host disease, each with distinct end-organ targets. J Clin Invest (2000) 105(9):1289-98. doi:10.1172/JCI7894

34. Korn T, Bettelli E, Oukka M, Kuchroo VK. IL-17 and Th17 Cells. Annu Rev Immunol (2009) 27:485-517. doi:10.1146/annurev.immunol.021908. 132710

35. van der Waart AB, van der Velden WJ, Blijlevens NM, Dolstra H. Targeting the IL17 pathway for the prevention of graft-versus-host disease. Biol Blood Marrow Transplant (2014) 20(6):752-9. doi:10.1016/j.bbmt.2014.02.007

36. Varelias A, Gartlan KH, Kreijveld E, Olver SD, Lor M, Kuns RD, et al. Lung parenchyma-derived IL-6 promotes IL-17A-dependent acute lung injury after allogeneic stem cell transplantation. Blood (2015) 125(15):2435-44. doi:10.1182/blood-2014-07-590232

37. Corthay A. How do regulatory T cells work? Scand J Immunol (2009) 70(4):326-36. doi:10.1111/j.1365-3083.2009.02308.x

38. Beres AJ, Drobyski WR. The role of regulatory T cells in the biology of graft versus host disease. Front Immunol (2013) 4:163. doi:10.3389/fimmu.2013. 00163

39. Bruserud O, Hamann W, Patel S, Ehninger G, Schmidt H, Pawelec G. IFN-gamma and TNF-alpha secretion by CD4+ and CD8+ TCR alpha beta + T-cell clones derived early after allogeneic bone marrow transplantation. Eur J Haematol (1993) 51(2):73-9. doi:10.1111/j.1600-0609.1993. tb01596.x

40. Mantovani A, Sica A, Sozzani S, Allavena P, Vecchi A, Locati M. The chemokine system in diverse forms of macrophage activation and polarization. Trends Immunol (2004) 25(12):677-86. doi:10.1016/j.it.2004.09.015

41. Henden AS, Hill GR. Cytokines in graft-versus-host disease. J Immunol (2015) 194(10):4604-12. doi:10.4049/jimmunol.1500117

42. Scheller J, Chalaris A, Schmidt-Arras D, Rose-John S. The pro- and antiinflammatory properties of the cytokine interleukin-6. Biochim Biophys Acta (2011) 1813(5):878-88. doi:10.1016/j.bbamcr.2011.01.034

43. Kleiner G, Marcuzzi A, Zanin V, Monasta L, Zauli G. Cytokine levels in the serumofhealthysubjects.MediatorsInflamm(2013)2013:434010.doi:10.1155/ 2013/434010

44. Fernandez-Real JM, Vayreda M, Richart C, Gutierrez C, Broch M, Vendrell J, et al. Circulating interleukin 6 levels, blood pressure, and insulin sensitivity in apparently healthy men and women. JClin Endocrinol Metab (2001) 86(3):1154-9. doi:10.1210/jcem.86.3.7305

45. Damas P, Ledoux D, Nys M, Vrindts Y, De Groote D, Franchimont P, et al. Cytokine serum level during severe sepsis in human IL-6 as a marker of severity. Ann Surg (1992) 215(4):356-62. doi:10.1097/00000658-19920400000009

46. Akira S, Taga T, Kishimoto T. Interleukin-6 in biology and medicine. $A d v$ Immunol (1993) 54:1-78. doi:10.1016/S0065-2776(08)60532-5

47. Hungness ES, Luo GJ, Pritts TA, Sun X, Robb BW, Hershko D, et al. Transcription factors C/EBP-beta and -delta regulate IL-6 production in IL-1beta-stimulated human enterocytes. J Cell Physiol (2002) 192(1):64-70. doi:10.1002/jcp.10116

48. Beetz A, Peter RU, Oppel T, Kaffenberger W, Rupec RA, Meyer M, et al. NF-kappaB and AP-1 are responsible for inducibility of the IL-6 promoter by ionizing radiation in HeLa cells. Int J Radiat Biol (2000) 76(11):1443-53. doi:10.1080/09553000050176207

49. Lin HY, Tang CH, Chen JH, Chuang JY, Huang SM, Tan TW, et al. Peptidoglycan induces interleukin-6 expression through the TLR2 receptor, JNK, c-Jun, and AP-1 pathways in microglia. J Cell Physiol (2011) 226(6):1573-82. doi:10.1002/jcp.22489

50. Hong DS, Angelo LS, Kurzrock R. Interleukin-6 and its receptor in cancer: implications for translational therapeutics. Cancer (2007) 110(9):1911-28. doi:10.1002/cncr.22999 
51. Naugler WE, Karin M. The wolf in sheep's clothing: the role of interleukin-6 in immunity, inflammation and cancer. Trends Mol Med (2008) 14(3):109-19. doi:10.1016/j.molmed.2007.12.007

52. Pedersen BK, Steensberg A, Schjerling P. Muscle-derived interleukin-6: possible biological effects. J Physiol (2001) 536(Pt 2):329-37. doi:10.1111/ j.1469-7793.2001.0329c.xd

53. Heink S, Yogev N, Garbers C, Herwerth M, Aly L, Gasperi C, et al. Trans-presentation of IL- 6 by dendritic cells is required for the priming of pathogenic TH17 cells. Nat Immunol (2017) 18(1):74-85. doi:10.1038/ ni.3632

54. Silver JS, Hunter CA. gp130 at the nexus of inflammation, autoimmunity, and cancer. J Leukoc Biol (2010) 88(6):1145-56. doi:10.1189/jlb.0410217

55. Cornelissen C, Lüscher-Firzlaff J, Baron JM, Lüscher B. Signaling by IL-31 and functional consequences. Eur J Cell Biol (2012) 91(6-7):552-66. doi:10.1016/j.ejcb.2011.07.006

56. Schaper F, Rose-John S. Interleukin-6: biology, signaling and strategies of blockade. Cytokine Growth Factor Rev (2015) 26(5):475-87. doi:10.1016/j. cytogfr.2015.07.004

57. Hong J, Wang H, Shen G, Lin D, Lin Y, Ye N, et al. Recombinant soluble gp130 protein reduces DEN-induced primary hepatocellular carcinoma in mice. Sci Rep (2016) 6:24397. doi:10.1038/srep24397

58. Nowell MA, Williams AS, Carty SA, Scheller J, Hayes AJ, Jones GW, et al. Therapeutic targeting of IL-6 trans signaling counteracts STAT3 control of experimental inflammatory arthritis. J Immunol (2009) 182(1):613-22. doi:10.4049/jimmunol.182.1.613

59. Atreya R, Mudter J, Finotto S, Müllberg J, Jostock T, Wirtz S, et al. Blockade of interleukin 6 trans signaling suppresses T-cell resistance against apoptosis in chronic intestinal inflammation: evidence in Crohn disease and experimental colitis in vivo. Nat Med (2000) 6(5):583-8. doi:10.1038/75068

60. Jones GW, McLoughlin RM, Hammond VJ, Parker CR, Williams JD, Malhotra R, et al. Loss of CD4+ T cell IL-6R expression during inflammation underlines a role for IL- 6 trans signaling in the local maintenance of Th17 cells. J Immunol (2010) 184(4):2130-9. doi:10.4049/jimmunol.0901528

61. Zhang H, Neuhöfer P, Song L, Rabe B, Lesina M, Kurkowski MU, et al. IL-6 trans-signaling promotes pancreatitis-associated lung injury and lethality. J Clin Invest (2013) 123(3):1019-31. doi:10.1172/JCI64931

62. Gruys E, Toussaint MJ, Niewold TA, Koopmans SJ. Acute phase reaction and acute phase proteins. JZhejiang Univ Sci B (2005) 6(11):1045-56. doi:10.1631/jzus.2005.B1045

63. Angelo LS, Talpaz M, Kurzrock R. Autocrine interleukin-6 production in renal cell carcinoma: evidence for the involvement of p53. Cancer Res (2002) 62(3):932-40.

64. Colombo MP, Maccalli C, Mattei S, Melani C, Radrizzani M, Parmiani G. Expression of cytokine genes, including IL-6, in human malignant melanoma cell lines. Melanoma Res (1992) 2(3):181-9. doi:10.1097/00008390199209000-00006

65. Jordan KK, Christensen IJ, Heilmann C, Sengeløv H, Müller KG. Pretransplant C-reactive protein as a prognostic marker in allogeneic stem cell transplantation. Scand J Immunol (2014) 79(3):206-13. doi:10.1111/sji.12137

66. Artz AS, Wickrema A, Dinner S, Godley LA, Kocherginsky M, Odenike O, et al. Pretreatment C-reactive protein is a predictor for outcomes after reduced-intensity allogeneic hematopoietic cell transplantation. Biol Blood Marrow Transplant (2008) 14(11):1209-16. doi:10.1016/j.bbmt.2008.08.004

67. Akı ŞZ, Suyanı E, Bildacı Y, Çakar MK, Baysal NA, Sucak GT. Prognostic role of pre-transplantation serum C-reactive protein levels in patients with acute leukemia undergoing myeloablative allogeneic stem cell transplantation. Clin Transplant (2012) 26(5):E513-21. doi:10.1111/ctr.12028

68. Sakamoto S, Kawabata H, Kanda J, Uchiyama T, Mizumoto C, Kondo T, et al. Differing impacts of pretransplant serum ferritin and C-reactive protein levels on the incidence of chronic graft-versus-host disease after allogeneic hematopoietic stem cell transplantation. Int J Hematol (2013) 97(1):109-16. doi:10.1007/s12185-012-1229-0

69. Sato M, Nakasone H, Oshima K, Ishihara Y, Wada H, Sakamoto K, et al. Prediction of transplant-related complications by C-reactive protein levels before hematopoietic SCT. Bone Marrow Transplant (2013) 48(5):698-702. doi:10.1038/bmt.2012.193

70. Remberger M, Mattsson J. C-reactive protein levels before reduced-intensity conditioning predict outcome after allogeneic stem cell transplantation. Int J Hematol (2010) 92(1):161-7. doi:10.1007/s12185-010-0632-7
71. Patel A, Szydlo RM, Auner HW, Kanfer EJ, MacDonald DH, Milojkovic D, et al. C-reactive protein prior to myeloablative allogeneic haematopoietic cell transplantation identifies patients at risk of early- and long-term mortality. Br J Haematol (2016). doi:10.1111/bjh.14454

72. Briso EM, Dienz O, Rincon M. Cutting edge: soluble IL-6R is produced by IL-6R ectodomain shedding in activated CD4 T cells. J Immunol (2008) 180(11):7102-6. doi:10.4049/jimmunol.180.11.7102

73. Dienz O, Rincon M. The effects of IL- 6 on CD4 T cell responses. Clin Immunol (2009) 130(1):27-33. doi:10.1016/j.clim.2008.08.018

74. Freeman AF, Domingo DL, Holland SM. Hyper IgE (Job’s) syndrome: a primary immune deficiency with oral manifestations. Oral Dis (2009) 15(1):2-7. doi:10.1111/j.1601-0825.2008.01463.x

75. Veldhoen M, Hocking RJ, Atkins CJ, Locksley RM, Stockinger B. TGFbeta in the context of an inflammatory cytokine milieu supports de novo differentiation of IL-17-producing T cells. Immunity (2006) 24(2):179-89. doi:10.1016/j.immuni.2006.01.001

76. Bettelli E, Carrier Y, Gao W, Korn T, Strom TB, Oukka M, et al. Reciprocal developmental pathways for the generation of pathogenic effector TH17 and regulatory T cells. Nature (2006) 441(7090):235-8. doi:10.1038/nature04753

77. Eyerich S, Eyerich K, Pennino D, Carbone T, Nasorri F, Pallotta S, et al. Th22 cells represent a distinct human $\mathrm{T}$ cell subset involved in epidermal immunity and remodeling. J Clin Invest (2009) 119(12):3573-85. doi:10.1172/JCI40202

78. McGeachy MJ, Bak-Jensen KS, Chen Y, Tato CM, Blumenschein W, McClanahan T, et al. TGF-beta and IL-6 drive the production of IL-17 and IL-10 by T cells and restrain T(H)-17 cell-mediated pathology. Nat Immunol (2007) 8(12):1390-7. doi:10.1038/ni1539

79. Choi YS, Eto D, Yang JA, Lao C, Crotty S. Cutting edge: STAT1 is required for IL-6-mediated Bcl6 induction for early follicular helper cell differentiation. J Immunol (2013) 190(7):3049-53. doi:10.4049/jimmunol.1203032

80. Ma CS, Deenick EK. Human T follicular helper (Tfh) cells and disease. Immunol Cell Biol (2014) 92(1):64-71. doi:10.1038/icb.2013.55

81. Djouad F, Charbonnier LM, Bouffi C, Louis-Plence P, Bony C, Apparailly F, et al. Mesenchymal stem cells inhibit the differentiation of dendritic cells through an interleukin-6-dependent mechanism. Stem Cells (2007) 25(8):2025-32. doi:10.1634/stemcells.2006-0548

82. Park SJ, Nakagawa T, Kitamura H, Atsumi T, Kamon H, Sawa S, et al. IL-6 regulates in vivo dendritic cell differentiation through STAT3 activation. J Immunol (2004) 173(6):3844-54. doi:10.4049/jimmunol.173.6.3844

83. Chomarat P, Banchereau J, Davoust J, Palucka AK. IL-6 switches the differentiation of monocytes from dendritic cells to macrophages. Nat Immunol (2000) 1(6):510-4. doi:10.1038/82763

84. Jourdan M, Cren M, Robert N, Bolloré K, Fest T, Duperray C, et al. IL-6 supports the generation of human long-lived plasma cells in combination with either APRIL or stromal cell-soluble factors. Leukemia (2014) 28(8):1647-56. doi:10.1038/leu.2014.61

85. Amorin B, Alegretti AP, Valim V, Pezzi A, Laureano AM, da Silva MA, et al. Mesenchymal stem cell therapy and acute graft-versus-host disease: a review. Hum Cell (2014) 27(4):137-50. doi:10.1007/s13577-014-0095-x

86. van Buul GM, Villafuertes E, Bos PK, Waarsing JH, Kops N, Narcisi R, et al. Mesenchymal stem cells secrete factors that inhibit inflammatory processes in short-term osteoarthritic synovium and cartilage explant culture. Osteoarthritis Cartilage (2012) 20(10):1186-96. doi:10.1016/j. joca.2012.06.003

87. Bouffi C, Bony C, Courties G, Jorgensen C, Noël D. IL-6-dependent PGE2 secretion by mesenchymal stem cells inhibits local inflammation in experimental arthritis. PLoS One (2010) 5(12):e14247. doi:10.1371/journal. pone.0014247

88. Nasef A, Mazurier C, Bouchet S, François S, Chapel A, Thierry D, et al. Leukemia inhibitory factor: role in human mesenchymal stem cells mediated immunosuppression. Cell Immunol (2008) 253(1-2):16-22. doi:10.1016/j. cellimm.2008.06.002

89. Kim N, Im KI, Lim JY, Jeon EJ, Nam YS, Kim EJ, et al. Mesenchymal stem cells for the treatment and prevention of graft-versus-host disease: experiments and practice. Ann Hematol (2013) 92(10):1295-308. doi:10.1007/ s00277-013-1796-z

90. Pricola KL, Kuhn NZ, Haleem-Smith H, Song Y, Tuan RS. Interleukin-6 maintains bone marrow-derived mesenchymal stem cell stemness by an ERK1/2-dependent mechanism. J Cell Biochem (2009) 108(3):577-88. doi:10.1002/jcb.22289 
91. Najar M, Rouas R, Raicevic G, Boufker HI, Lewalle P, Meuleman N, et al. Mesenchymal stromal cells promote or suppress the proliferation of $\mathrm{T}$ lymphocytes from cord blood and peripheral blood: the importance of low cell ratio and role of interleukin-6. Cytotherapy (2009) 11(5):570-83. doi:10.1080/14653240903079377

92. Kraybill WG, Olenki T, Evans SS, Ostberg JR, O'Leary KA, Gibbs JF, et al. A phase I study of fever-range whole body hyperthermia (FR-WBH) in patients with advanced solid tumours: correlation with mouse models. Int J Hyperthermia (2002) 18(3):253-66. doi:10.1080/02656730110116704

93. von Andrian UH, Mempel TR. Homing and cellular traffic in lymph nodes. Nat Rev Immunol (2003) 3(11):867-78. doi:10.1038/nri1222

94. Appenheimer MM, Girard RA, Chen Q, Wang WC, Bankert KC, Hardison J, et al. Conservation of IL- 6 trans-signaling mechanisms controlling L-selectin adhesion by fever-range thermal stress. Eur JImmunol (2007) 37(10): 2856-67. doi:10.1002/eji.200636421

95. Vardam TD, Zhou L, Appenheimer MM, Chen Q, Wang WC, Baumann H, et al. Regulation of a lymphocyte-endothelial-IL-6 trans-signaling axis by fever-range thermal stress: hot spot of immune surveillance. Cytokine (2007) 39(1):84-96. doi:10.1016/j.cyto.2007.07.184

96. Galun E, Zeira E, Pappo O, Peters M, Rose-John S. Liver regeneration induced by a designer human IL-6/sIL-6R fusion protein reverses severe hepatocellular injury. FASEB J (2000) 14(13):1979-87. doi:10.1096/f.99$0913 \mathrm{com}$

97. Peters M, Blinn G, Jostock T, Schirmacher P, Meyer zum Büschenfelde KH, Galle PR, et al. Combined interleukin 6 and soluble interleukin 6 receptor accelerates murine liver regeneration. Gastroenterology (2000) 119(6):1663-71. doi:10.1053/gast.2000.20236

98. Drepper M, Rubbia-Brandt L, Spahr L. Tocilizumab-induced acute liver injury in adult onset still's disease. Case Reports Hepatol (2013) 2013:964828. doi: $10.1155 / 2013 / 964828$

99. Ernst M, Thiem S, Nguyen PM, Eissmann M, Putoczki TL. Epithelial gp130/ Stat3 functions: an intestinal signaling node in health and disease. Semin Immunol (2014) 26(1):29-37. doi:10.1016/j.smim.2013.12.006

100. Kuhn KA, Manieri NA, Liu TC, Stappenbeck TS. IL-6 stimulates intestinal epithelial proliferation and repair after injury. PLoS One (2014) 9(12):e114195. doi:10.1371/journal.pone.0114195

101. Waldner MJ, Neurath MF. Master regulator of intestinal disease: IL-6 in chronic inflammation and cancer development. Semin Immunol (2014) 26(1):75-9. doi:10.1016/j.smim.2013.12.003

102. Yamamoto M, Yoshizaki K, Kishimoto T, Ito H. IL-6 is required for the development of Th1 cell-mediated murine colitis. JImmunol (2000) 164(9):4878-82. doi:10.4049/jimmunol.164.9.4878

103. Gout T, Ostor AJ, Nisar MK. Lower gastrointestinal perforation in rheumatoid arthritis patients treated with conventional DMARDs or tocilizumab: a systematic literature review. Clin Rheumatol (2011) 30(11):1471-4. doi:10.1007/s10067-011-1827-x

104. Roytblat L, Rachinsky M, Fisher A, Greemberg L, Shapira Y, Douvdevani A, et al. Raised interleukin-6 levels in obese patients. Obes Res (2000) 8(9):673-5. doi:10.1038/oby.2000.86

105. Bastard JP, Jardel C, Bruckert E, Blondy P, Capeau J, Laville M, et al. Elevated levels of interleukin 6 are reduced in serum and subcutaneous adipose tissue of obese women after weight loss. J Clin Endocrinol Metab (2000) 85(9):3338-42. doi:10.1210/jc.85.9.3338

106. Goyal R, Faizy AF, Siddiqui SS, Singhai M. Evaluation of TNF-alpha and IL-6 levels in obese and non-obese diabetics: pre- and postinsulin effects. N Am J Med Sci (2012) 4(4):180-4. doi:10.4103/1947-2714.94944

107. Mauer J, Chaurasia B, Goldau J, Vogt MC, Ruud J, Nguyen KD, et al. Signaling by IL-6 promotes alternative activation of macrophages to limit endotoxemia and obesity-associated resistance to insulin. Nat Immunol (2014) 15(5):423-30. doi:10.1038/ni.2865

108. Singh JA, Beg S, Lopez-Olivo MA. Tocilizumab for rheumatoid arthritis: a cochrane systematic review. J Rheumatol (2011) 38(1):10-20. doi:10.3899/ jrheum.100717

109. Muñoz-Cánoves P, Scheele C, Pedersen BK, Serrano AL. Interleukin-6 myokine signaling in skeletal muscle: a double-edged sword? FEBS J (2013) 280(17):4131-48. doi:10.1111/febs.12338

110. Givon T, Revel M, Slavin S. Potential use of interleukin-6 in bone marrow transplantation: effects of recombinant human interleukin- 6 after syngeneic and semiallogeneic bone marrow transplantation in mice. Blood (1994) 83(6):1690-7.

111. Chen X, Das R, Komorowski R, Beres A, Hessner MJ, Mihara M, et al. Blockade of interleukin-6 signaling augments regulatory T-cell reconstitution and attenuates the severity of graft-versus-host disease. Blood (2009) 114(4):891-900. doi:10.1182/blood-2009-01-197178

112. Noguchi D, Wakita D, Ohkuri T, Tajima M, Chamoto K, Kitamura H, et al. Blockade of IL-6-signaling inhibits the pathogenesis of CD4+ T cell-mediated lethal graft-versus-host reaction against minor histocompatibility antigen. Immunol Lett (2011) 136(2):146-55. doi:10.1016/j.imlet.2011.01.004

113. Tawara I, Koyama M, Liu C, Toubai T, Thomas D, Evers R, et al. Interleukin-6 modulates graft-versus-host responses after experimental allogeneic bone marrow transplantation. Clin Cancer Res (2011) 17(1):77-88. doi:10.1158/1078-0432.CCR-10-1198

114. Le Huu D, Matsushita T, Jin G, Hamaguchi Y, Hasegawa M, Takehara K, et al. IL- 6 blockade attenuates the development of murine sclerodermatous chronic graft-versus-host disease. J Invest Dermatol (2012) 132(12):2752-61. doi:10.1038/jid.2012.226

115. Lee SH, Moon SJ, Park MJ, Kim EK, Moon YM, Cho ML. PIAS3 suppresses acute graft-versus-host disease by modulating effector $\mathrm{T}$ and $\mathrm{B}$ cell subsets through inhibition of STAT3 activation. Immunol Lett (2014) 160(1):79-88. doi:10.1016/j.imlet.2014.03.014

116. Lu SX, Alpdogan O, Lin J, Balderas R, Campos-Gonzalez R, Wang X, et al. STAT-3 and ERK 1/2 phosphorylation are critical for T-cell alloactivation and graft-versus-host disease. Blood (2008) 112(13):5254-8. doi:10.1182/ blood-2008-03-147322

117. Betts BC, Abdel-Wahab O, Curran SA, St Angelo ET, Koppikar P, Heller $\mathrm{G}$, et al. Janus kinase-2 inhibition induces durable tolerance to alloantigen by human dendritic cell-stimulated $\mathrm{T}$ cells yet preserves immunity to recall antigen. Blood (2011) 118(19):5330-9. doi:10.1182/blood-2011-06363408

118. Betts BC, Sagatys EM, Veerapathran A, Lloyd MC, Beato F, Lawrence $\mathrm{HR}$, et al. CD4+ T cell STAT3 phosphorylation precedes acute GVHD, and subsequent Th17 tissue invasion correlates with GVHD severity and therapeutic response. J Leukoc Biol (2015) 97(4):807-19. doi:10.1189/jlb. 5A1114-532RR

119. Laurence A, Amarnath S, Mariotti J, Kim YC, Foley J, Eckhaus M, et al. STAT3 transcription factor promotes instability of nTreg cells and limits generation of iTreg cells during acute murine graft-versus-host disease. Immunity (2012) 37(2):209-22. doi:10.1016/j.immuni.2012.05.027

120. Radojcic V, Pletneva MA, Yen HR, Ivcevic S, Panoskaltsis-Mortari A, Gilliam AC, et al. STAT3 signaling in CD4+ T cells is critical for the pathogenesis of chronic sclerodermatous graft-versus-host disease in a murine model. J Immunol (2010) 184(2):764-74. doi:10.4049/jimmunol. 0903006

121. Spoerl S, Mathew NR, Bscheider M, Schmitt-Graeff A, Chen S, Mueller T, et al. Activity of therapeutic JAK 1/2 blockade in graft-versus-host disease. Blood (2014) 123(24):3832-42. doi:10.1182/blood-2013-12-543736

122. Zeiser R, Burchert A, Lengerke C, Verbeek M, Maas-Bauer K, Metzelder SK, et al. Ruxolitinib in corticosteroid-refractory graft-versus-host disease after allogeneic stem cell transplantation: a multicenter survey. Leukemia (2015) 29(10):2062-8. doi:10.1038/leu.2015.212

123. Terry CF, Loukaci V, Green FR. Cooperative influence of genetic polymorphisms on interleukin 6 transcriptional regulation. J Biol Chem (2000) 275(24):18138-44. doi:10.1074/jbc.M000379200

124. Fishman D, Faulds G, Jeffery R, Mohamed-Ali V, Yudkin JS, Humphries S, et al. The effect of novel polymorphisms in the interleukin-6 (IL-6) gene on IL- 6 transcription and plasma IL-6 levels, and an association with systemic-onset juvenile chronic arthritis. J Clin Invest (1998) 102(7):1369-76. doi:10.1172/JCI2629

125. Ambruzova Z, Mrazek F, Raida L, Faber E, Onderkova J, Kriegova E, et al. Association of IL-6 gene polymorphism with the outcome of allogeneic haematopoietic stem cell transplantation in Czech patients. Int J Immunogenet (2008) 35(4-5):401-3. doi:10.1111/j.1744-313X.2008.00798.x

126. Ambruzova Z, Mrazek F, Raida L, Jindra P, Vidan-Jeras B, Faber E, et al. Association of IL6 and CCL2 gene polymorphisms with the outcome of allogeneic haematopoietic stem cell transplantation. Bone Marrow Transplant (2009) 44(4):227-35. doi:10.1038/bmt.2009.16 
127. Cavet J, Dickinson AM, Norden J, Taylor PR, Jackson GH, Middleton PG. Interferon-gamma and interleukin-6 gene polymorphisms associate with graft-versus-host disease in HLA-matched sibling bone marrow transplantation. Blood (2001) 98(5):1594-600. doi:10.1182/blood.V98. 5.1594

128. Chien JW, Zhang XC, Fan W, Wang H, Zhao LP, Martin PJ, et al. Evaluation of published single nucleotide polymorphisms associated with acute GVHD. Blood (2012) 119(22):5311-9. doi:10.1182/blood-2011-09-371153

129. Kim D, Won HH, Su S, Cheng L, Xu W, Hamad N, et al. Risk stratification of organ-specific GVHD can be improved by single-nucleotide polymorphism-based risk models. Bone Marrow Transplant (2014) 49(5):649-56. doi:10.1038/bmt.2014.20

130. KimDD, YunJ,Won HH, ChengL, SuJ,XuW, etal. Multiplesingle-nucleotide polymorphism-based risk model for clinical outcomes after allogeneic stem-cell transplantation, especially for acute graft-versushost disease. Transplantation (2012) 94(12):1250-7. doi:10.1097/ TP.0b013e3182708e7c

131. Laguila Visentainer JE, Lieber SR, Lopes Persoli LB, Dutra Marques SB, Vigorito AC, Penteado Aranha FJ, et al. Relationship between cytokine gene polymorphisms and graft-versus-host disease after allogeneic stem cell transplantation in a Brazilian population. Cytokine (2005) 32(3-4):171-7. doi:10.1016/j.cyto.2005.09.002

132. Lin MT, Storer B, Martin PJ, Tseng LH, Gooley T, Chen PJ, et al. Relation of an interleukin-10 promoter polymorphism to graft-versus-host disease and survival after hematopoietic-cell transplantation. N Engl J Med (2003) 349(23):2201-10. doi:10.1056/NEJMoa022060

133. Alam N, Xu W, Atenafu EG, Uhm J, Seftel M, Gupta V, et al. Risk model incorporating donor IL6 and IFNG genotype and gastrointestinal GVHD can discriminate patients at high risk of steroid refractory acute GVHD. Bone Marrow Transplant (2015) 50(5):734-42. doi:10.1038/bmt. 2015.19

134. Karabon L, Wysoczanska B, Bogunia-Kubik K, Suchnicki K, Lange A. IL-6 and IL-10 promoter gene polymorphisms of patients and donors of allogeneic sibling hematopoietic stem cell transplants associate with the risk of acute graft-versus-host disease. Hum Immunol (2005) 66(6):700-10. doi:10.1016/j. humimm.2005.02.003

135. Socié G, Loiseau P, Tamouza R, Janin A, Busson M, Gluckman E, et al. Both genetic and clinical factors predict the development of graft-versushost disease after allogeneic hematopoietic stem cell transplantation. Transplantation (2001) 72(4):699-706. doi:10.1097/00007890-20010827000024

136. Rocha V, Franco RF, Porcher R, Bittencourt H, Silva WA Jr, Latouche A, et al. Host defense and inflammatory gene polymorphisms are associated with outcomes after HLA-identical sibling bone marrow transplantation. Blood (2002) 100(12):3908-18. doi:10.1182/blood-2002-04-1033

137. Mullighan C, Heatley S, Doherty K, Szabo F, Grigg A, Hughes T, et al. NonHLA immunogenetic polymorphisms and the risk of complications after allogeneic hemopoietic stem-cell transplantation. Transplantation (2004) 77(4):587-96. doi:10.1097/01.TP.0000111769.45088.A2

138. Choi B, Lee DE, Park HY, Jeong S, Lee SM, Ji E, et al. A meta-analysis of the effects of interleukin-6 -174 G>C genetic polymorphism on acute graft-versus-host disease susceptibility. Clin Ther (2012) 34(2):295-304. doi:10.1016/j.clinthera.2012.01.010

139. Ferreira RC, Freitag DF, Cutler AJ, Howson JM, Rainbow DB, Smyth DJ, et al. Functional IL6R 358Ala allele impairs classical IL-6 receptor signaling and influences risk of diverse inflammatory diseases. PLoS Genet (2013) 9(4):e1003444. doi:10.1371/journal.pgen.1003444

140. Ferra C, de Sanjosé S, Gallardo D, Berlanga JJ, Rueda F, Marìn D, et al. IL-6 and IL-8 levels in plasma during hematopoietic progenitor transplantation. Haematologica (1998) 83(12):1082-7.

141. Steffen M, Pichlmeier U, Zander A. Inverse correlation of interleukin-6 with soluble interleukin-6 receptor after transplantation of bone marrow or peripheral blood stem cells. Bone Marrow Transplant (1997) 20(9):715-20. doi:10.1038/sj.bmt.1700936

142. Mouawad R, Soubrane C, Rixe O, Khayat D, Spano JP. An unexpected inverse correlation between soluble epidermal growth factor receptor and interleukin-6 in metastatic malignant melanoma patients. Melanoma Res (2006) 16(4):335-40. doi:10.1097/01.cmr.0000205022.25397.86
143. Liem LM, van Houwelingen HC, Goulmy E. Serum cytokine levels after HLAidentical bone marrow transplantation. Transplantation (1998) 66(7):863-71. doi:10.1097/00007890-199810150-00009

144. Bruserud O, Akselen PE, Bergheim J, Nesthus I. Serum concentrations of E-selectin, P-selectin, ICAM-1 and interleukin 6 in acute leukaemia patients with chemotherapy-induced leucopenia and bacterial infections. $\mathrm{Br}$ J Haematol (1995) 91(2):394-402. doi:10.1111/j.1365-2141.1995. tb05309.x

145. Symington FW, Symington BE, Liu PY, Viguet H, Santhanam U, Sehgal PB. The relationship of serum IL-6 levels to acute graft-versus-host disease and hepatorenaldiseaseafterhumanbonemarrowtransplantation. Transplantation (1992) 54(3):457-62. doi:10.1097/00007890-199209000-00014

146. Imamura M, Hashino S, Kobayashi H, Kubayashi S, Hirano S, Minagawa $\mathrm{T}$, et al. Serum cytokine levels in bone marrow transplantation: synergistic interaction of interleukin-6, interferon-gamma, and tumor necrosis factor-alpha in graft-versus-host disease. Bone Marrow Transplant (1994) 13(6):745-51.

147. Chasty RC, Lamb WR, Gallati H, Roberts TE, Brenchley PE, Yin JA. Serum cytokine levels in patients undergoing bone marrow transplantation. Bone Marrow Transplant (1993) 12(4):331-6.

148. Rowbottom AW, Riches PG, Downie C, Hobbs JR. Monitoring cytokine production in peripheral blood during acute graft-versus-host disease following allogeneic bone marrow transplantation. Bone Marrow Transplant (1993) 12(6):635-41.

149. Min CK, Lee WY, Min DJ, Lee DG, Kim YJ, Park YH, et al. The kinetics of circulating cytokines including IL-6, TNF-alpha, IL-8 and IL-10 following allogeneic hematopoietic stem cell transplantation. Bone Marrow Transplant (2001) 28(10):935-40. doi:10.1038/sj.bmt.1703258

150. Tegg EM, Griffiths AE, Lowenthal RM, Tuck DM, Harrup R, Marsden KA, et al. Association between high interleukin-6 levels and adverse outcome after autologous haemopoietic stem cell transplantation. Bone Marrow Transplant (2001) 28(10):929-33. doi:10.1038/sj.bmt.1703272

151. Yao X, Huang J, Zhong H, Shen N, Faggioni R, Fung M, et al. Targeting interleukin-6 in inflammatory autoimmune diseases and cancers. Pharmacol Ther (2014) 141(2):125-39. doi:10.1016/j.pharmthera.2013.09.004

152. Emery P, Keystone E, Tony HP, Cantagrel A, van Vollenhoven R, Sanchez A et al. IL-6 receptor inhibition with tocilizumab improves treatment outcomes in patients with rheumatoid arthritis refractory to anti-tumour necrosis factor biologicals: results from a 24-week multicentre randomised placebo-controlled trial. Ann Rheum Dis (2008) 67(11):1516-23. doi:10.1136/ ard.2008.092932

153. Maini RN, Taylor PC, Szechinski J, Pavelka K, Bröll J, Balint G, et al. Doubleblind randomized controlled clinical trial of the interleukin- 6 receptor antagonist, tocilizumab, in European patients with rheumatoid arthritis who had an incomplete response to methotrexate. Arthritis Rheum (2006) 54(9):2817-29. doi:10.1002/art.22033

154. Smolen JS, Beaulieu A, Rubbert-Roth A, Ramos-Remus C, Rovensky J, Alecock E, et al. Effect of interleukin- 6 receptor inhibition with tocilizumab in patients with rheumatoid arthritis (OPTION study): a double-blind, placebo-controlled, randomised trial. Lancet (2008) 371(9617):987-97. doi:10.1016/S0140-6736(08)60453-5

155. Kennedy GA, Varelias A, Vuckovic S, Le Texier L, Gartlan KH, Zhang P, et al. Addition of interleukin-6 inhibition with tocilizumab to standard graft-versus-host disease prophylaxis after allogeneic stem-cell transplantation: a phase 1/2 trial. Lancet Oncol (2014) 15(13):1451-9. doi:10.1016/ S1470-2045(14)71017-4

156. Nishida S, Kawasaki T, Kashiwagi H, Morishima A, Hishitani Y, Kawai M, et al. Successful treatment of acquired hemophilia A, complicated by chronic GVHD, with tocilizumab. Mod Rheumatol (2011) 21(4):420-2. doi:10.1007/ s10165-010-0411-6

157. Kolb M, Bhatia M, Madina GG, Satwani P. Effective use of tocilizumab for the treatment of steroid-refractory gastrointestinal acute graft versus host disease in a child with very high levels of serum interleukin-6. Pediatr Blood Cancer (2015) 62(2):362-3. doi:10.1002/pbc.25231

158. Gergis U, Arnason J, Yantiss R, Shore T, Wissa U, Feldman E, et al. Effectiveness and safety of tocilizumab, an anti-interleukin- 6 receptor monoclonal antibody, in a patient with refractory GI graft-versus-host disease. J Clin Oncol (2010) 28(30):e602-4. doi:10.1200/JCO.2010.29.1682 
159. Ganetsky A, Frey NV, Loren AW, Hexner EO, Mangan JK, Gill SI, et al. Tocilizumab is highly active for severe steroid-refractory acute graftversus-host disease of the gastrointestinal tract. ASH Annual Meeting. San Diego (2016).

160. Roddy JV, Haverkos BM, McBride A, Leininger KM, Jaglowski S, Penza S, et al. Tocilizumab for steroid refractory acute graft-versus-host disease. Leuk Lymphoma (2016) 57(1):81-5. doi:10.3109/10428194.2015.1045896

161. Drobyski WR, Pasquini M, Kovatovic K, Palmer J, Douglas Rizzo J, Saad A, et al. Tocilizumab for the treatment of steroid refractory graft-versus-host disease. Biol Blood Marrow Transplant (2011) 17(12):1862-8. doi:10.1016/j. bbmt.2011.07.001
Conflict of Interest Statement: The authors declare that the research was conducted in the absence of any commercial or financial relationships that could be construed as a potential conflict of interest.

Copyright (c) 2017 Tvedt, Ersvaer, Tveita and Bruserud. This is an open-access article distributed under the terms of the Creative Commons Attribution License (CC BY). The use, distribution or reproduction in other forums is permitted, provided the original author(s) or licensor are credited and that the original publication in this journal is cited, in accordance with accepted academic practice. No use, distribution or reproduction is permitted which does not comply with these terms. 